\title{
OJCOWIE KOŚCIOŁA A PRZERYWANIE CIĄŻY
}

Przekazywanie, pielęgnowanie i wycnowywanie życia ludzkiego to jedno z naczelnych zadan rodziny. Zadanie to było w ostatnim 50-leciu wielokrotnie podkreślane 1 przypominane przez Najwyżsy Nauczycielski Urząd Kościoła. Wystarczy tu wspomnieć encykliki "Casti connubi1" Piusa XI 1 "Humanae vitae" Pawła VI, Deklaracje - przerywantu ciązy Swiętej Kongregacji do Spraw Wiary, dyskusje 1 końcowy dokument VI Synodu Biskupów o zadaniach rodziny w świecle współczesnym, a szczególnie ostatnio adhortacje apostolską "Familiaris consortio" Jana Pawła II, głosząca, że płód ludzki od pierwszej chwili swego poczęcia jest człowiekiem, a jego umyślne zniszczenie jest morderstwem. Winnymi zaś tego mordu sa zarówno matka, która się takiego czynu dopuszcza, jak też ci wszyscy którzy czynnie z nią współpracują. Tak w tych wypowiedziach, jak 1 w całym morzu współczesnej literatury na ten temat, razi jaskrawo brak obszerniejszego pogłębienia historycznego: jak na problem sztucznego przerywania ciazy/procuratio abortus/zapatrywano sie w pierwszych wiekach chrześcijanstwa? Czy 1 jakim stopniu ojcowie Kościoła uwaźall procuratio abortus za zab́jstwo człowieka? Postawiony problem ma juz stosunkowo duża literaturę ${ }^{1}$, choc

1 Por. A.Albertario, "Conceptus pro iam nato habetur". Linee di una ricerca storico-dommatica, in: Studi in diritto romano, I, Milano 1933, 5,23-27; C.Appleton, La longévité et l'avortement volontalre aux premiers siecles de notre ere avec un tableau de statistique comparée, Lyon 1920; K.Bockmahl, Die Beurteilung der Abtreibung in der Frahzeit der christlichen Kirchen, "Theologische Beitrage" 3/1972/34-43; J.Connery, Abortion: the development of the catholic perspective, Loyola 1977, 33-65; J.Delmaille, Avortement. Histoire de la legislation, "Dictionnaire de droit canonique", I, 1537-1539; F.J.D8lger, Das Lebensrecht des ungeborenen Kindes und die Fruchtabtreibung in der Bewertung der heldnischen und christlichen Antike, ACh 4/1934/ 1-61; C.Palomo Gonzalez, Doctrina de san Agustin sobre la malicia del aborto y sa influencia en la disciplina penitencial de la Edad Media, diss. Salamanca 1959; G.Grisez, Abortion: The myths, the realities and the arguments, New York 1972, 117-184; H.Honings, Aborto /in antichità cristiana/, DPAC I 10-12; J.Lach, Milczenie BIblii wokóz problemu usuwania płodu z łona matki, CT 52/1982/z.3, 57-65; E.Nardi, Procurato aboto nel mondo greco-romano, Milano 
w języku polskim brak na ten temat jakiejś całościowej obszerniejszej wypowiedzi. Na szczególna uwage zasługują tu dwa monumentalne opracowania: F.J.Dolger, Das Lebensrecht des ungeborenen Kindes und die Fruchtabtreibung in der Bewertung der heidnischen und christlichen Antike, ACh 4/1933/3-61, oraz: E.Nardi, Procurato aborto nel mondo greco romano, Milano 1971. W naszym artykule pragniemy podać Czytelnikom względnie pelną panoramę wypowiedzi autorów 1 synodów pierwszych ośmiu wieków chrześcijaństwa wschodniego 1 zachodniego na temat przerywania ciaży. Aby zaś te wypowiedzi, niekiedy dwuznaczne i niezdecydowane były dla nas lepiej zrozumiałe i uzasadnione, przedstawimy je na tle szerokiego kontekstu historycznego, wkład którego wejdą odpowiedzi na takie pytania, jak: czy w czasach przedchrześcijańskich praktykowane było sztuczne przerywanie ciaży i zakich powodów? Jak do tego rodzaju działalności podchodziło prawo? Czym był płód w ocenie ówczesnej filozofil 1 medycyny? Chrześcijanie bowiem żyl1 wonkretnym kontekście historycznym, uwarunk owanym wielowlekowa tradycja, praktyka, zapatrywaniami, które mimo przyjęcia Dobrej Nowiny, nadal na nich w większyn lub mniejszym stopniu ciążyły i oddziaływały.

\section{P:ZERYTANIE CIAZZY W OKHESIE PIZEDCIIZZEŚCIJANSKIM}

od najdawniejszych czasów zapisanej kultury ludzkiej można zaobserwować dwa przeciwstawne zjawiska dotyczace dziecka: z jed-

1971, 301-685; J.T.Noonan, The Catholic Church and Abortion, "The Dublin Review" 241/1967-1968/300-345; J.T.Noonan, Abortion and the Catholic Church: a summary history, "Natural Law Forum" 12/1967/ 8587; J.Palazzini, Ius foetus ad vitam eiusque tutela in fontibus ac doctrina canonica usque ad saeculum XVI, Roma 1943, 9-80, 91-92, 174-183, 197-204; R. Roberge, L'avortement dans la pensée chrétienne des premiers siecles, "Collection d'Etudes Anciennes" 7/1977/ 83-90; M. loberti, "Nasciturus pro jam nato habetur" nelle fonti cristiane primitive, in: Cristianesimo e diritto romano, Milano 1935, 65-84; B.Sch8pf, Das Totungsrecht bei den fruhchristlichen Schriftstellern, llegensburg 1958, 112-142; B. Sesbolé, Les chrétiens devant l'avortement d'aprés le témoignage des Pères de l'Église, "Etudes" 339/1973/263-282; S.Vicastillo, Homicidii festinatio /Tertuliano, Apologetico 9,8/, "Augustinianum" 17/1977/425-428; J.W.Waszink, Abtrelbung. Nichtchristlich und christlich, iACh I $55-60$. 
nej strony uważano dzieci w rodzinie za wyraz błogosławieństwa bożego i na wszelki sposób starano siąz zabezpieczyć ich posiadanie ${ }^{2}$, traktując bezpłodność za wyraz kary bogów i powód do rozkładu małzeństwa, z drugiej zaś niekiedy z błahych powodów przeciwdziazano $1 \mathrm{ch}$ poczęciu ${ }^{3}$, przerywano ciaże $e^{4}$, zabijano albo porzucano no-

2 Starożytność znała nie tylko opiekuńcze bóstwa płodności, ale również stosowanie śwį̨tych kąpieli i picie świętej wody, które miały zapewnić lub przywrócić płodność. Obok tych środków religijnych płodność 1 łatwy poród zapewniały również medycyna ludowa, specjalne amulety i czary. Tak np. Pliniusz Starszy /23-79/ zalecał brzemiennej noszenie w celach przeciwporonieniowych szlachetnego kamienia, któryin wcześniej dotknięto głowy składanego na ofiare zwierzecia / Naturalis historia XXXVI 151 i XXX 130/; środek ten zalecał jeszcze w IV wieku Solinus/Collectanea rerum memorabilium XXXVII $5 /$.

3 Por. E.Eyben, Family planning in the Graeco-Roman Antiquity, "Ancient Society" 11-12/1980-1981/5-82; N.E.Himmes, Medical history of contraception, New York 1963, 70-101; K.Hopkins, Contraception and abortion in the toman Empire, "Comparative Studies in Society and History" 8/1965-1966/124-151; J.T.Noonan, Contraception. A history of its treatment by the catholic theologians and canonists Cambridge 1966, 9-91; A.Landry, La depopulation dans l'antiquité greco-romaine, RevH $177 / 1936 / 1-33$.

4 Por. C.H.Brecht, Partus abact10, IE XVIII, 4, 2046-2048; E.Caillemer, Ambloseos graphe, DAGR I 224-225; P.J.Carrick, Ancient Greek ethical perspectives on abortion and euthanasia, diss., Philadelphia 1982; h. Crahay, Les moralistes anciens et 1 'avortement, "L'Ant1quite Classique" 10/1941/ 9-23; S.K.Dickison, Abortion in Antiquity, "Arethusa" 6/1973/ 159-166; J.H.Hartmann, Abortio, RE I 108; R.Hahnel, Die kthstilche Abortus im Altertum, "Sudhoffs Archiv fur Geschichte der Medizin" 29/1936/224-255; G. Humbert, Abigere partum, DAGR I 7-8; G.Humbert, Abortio, DAGll I 9-10; Kieinfeller, Medicamenta mala, $\mathrm{kE} \mathrm{XV,} \mathrm{1,80;} \mathrm{W.A.Krenkel,}$ Erotica I: Der Abortus in der Antike, "Wissenschaftiche Zeitschrift der Wilhelm Pieck Universitat" 20/1971/443-452; Th. Mayer-Maly, Abortio, Der Kleine Pauly: Lexicon der Antike, I 16-17; M.Molssides, Contribution à l'étude de l'avortement dans l'antiquité grecque, "Janus" 25/1921/59-85, 129-145; U.A.Monpin, L'avortement provoqué dans l'antiquité,,diss., Paris 1918;

E. Nardi, Aborto e omicidio nella civilta classica, in: Aufstieg und Niedergang der r bmischen Welt, II 13, 1980,366-385; E.Nardi, Aborto e denaro in antichi dati, "lendiconti dell'Accademia delle Scienze dell'Istituto di Bologna" 65/1976-1977/29-33, 43-47; E.Nard1, La donna antica nel dramma del voluto aborto, in: Misoginia e maschilismo in Grecia e in toma, Bologna 1981, 9-26; E. Nardi, Procurato aborto nel mondo greco-romano, Milano 1971; Thalheim, Amblosis, RE I 2, 1804-1805. 
worodki skazując je na śmierć lub niewolnictwo ${ }^{5}$.

Charakteryzując okres przedchrześcijaŕski w relacji do procuratio abortus, przyjrzymy sie szkicowo, jak na jego temat wypowiadały sił ówczesne źródła literackie, filozoficzne, prawnicze, medyczne 1 biblijne.

$$
\text { Jeśli chodzi o z } r \text { ó } d z \text { a } l i t \text { e } r \text { a c k } 1 \text { e, to }
$$

- sztucznym przerywaniu ciazży wypowiada sie juz wedyjska literatu-

5 Por. Plutarchus, Vitae. Licurgos 13, cyt. za: Powszechna historia państwa i prawa, wyd. B.Lesiński 1 J.Walachowicz, Poznań 1969, 26: "0jciec nie musiał chować narodzonego dziecka, lecz zanosił je na zebranie członków tej samej fyli, gdzie najstarsi oglądali maleństwo; jeśli było silne $i$ dobrze zbudoware, kazali je żywí́ i przydzielali mu jeden z 9000 działów. Chuderlawe i niekształtne odsyłali na tzw. Odłóg, miejscowości pełnej przepaści koło Tajgetu, ponieważ sądzili, ze i dla niego samego i dla państwa jest lepiej, by nie żyło, jeżeli natura od początku nie dała mu zdrowia i siły"; Aristoteles, Politica VII, 14,10, 1335b:" kwestil usuwania czy wychowywania noworodków winno obowiazywać prawo, by nie wychowywać zadnego dziecka kalekiego"; L.Armaroli, Ricerche storiche sulla esposizione degli infanti presso gli anticni popoli e specialmente presso i romani, Venezia 1838; A.Becker, Die Behandlung verlassener Kinder im klassischen Altertum, Frankfurt 1871; H.Bennet, The exposure of infants in ancient Rome, "The Classical Journal" 18/1922-1923/341-351; J.Biezuńska-Małowist, Die expositio von Kindern als Quelle der Sklavenbeschaffung im griechisch-romischen Agypten, "Jahrbuch fur Wirtschaftsgeschichte" 1971, 2,129-133; H.Bolkestein, The exposure of children at Athens, "Classical Philology" 17/1922/ 222-239; A.Cameron, The exposure of Children and Greek Eth1cs, "Classical heview" 46/1932/ 105-114; D.Engels, Problem of female infanticide in the Graeco-Roman World, "Classical Philology" $75 / 1980 / 112-120$; L. $2 . F$. Germain, L'exposition des enfants nouveau-nés et l'infanticide dans la Grèce antique, Paris 1966; L. ll.F. Germain, Aspects du droit d'exposition en Grèce, "ilevue historique de droit Prancais" 47/1969/ 177-197; G.Glotz - H.Humbert, Expositio, DAGR II 930-939; G.Glotz, L'exposition des enfants, in: Etudes sociales et juridiques sur l'antiquité grecque, Paris 1906, 187-227; G.Glotz-E.Cuq, Infanticidium, DAGl III 488-493; M.Golden, Demography and the exposure of girls at Athens, "Phoenix" 35/1981/316-331; H. Handke, Die Kindestytung. iechtshistorisch und rechtsvergleichend, Breslau 1937; H. Henne, L'exposition des enfants dans l'antiquité. Ses aspects juridiques et sociologiques, Paris 1955; L. van llook, The exposure of infants at Athens, "Transactions and Proceedings of the American Philological Association Cleveland" 51/1920/134-145; K.Korus, Grecka teoria pedagogiczna a problew porzucania dzieci, "Meander" 34/1979/439-454; H.Kupiszewski, Porzucanie dziecka w prawach antycznych, "Meander" 11/1956/57-67; F.Lanfrancili, "Ius exponendi" e obbligo alinentare nel Diritto romano classico, SD!II 6/1940/5-69; L.W.Langer, Infanticide: a historical survey, 
ra religijna - Atharvaveda ok. 1500 lat przed Chrystusem uwazając je za najcięźszy z możliwych grzechów. Nie mówi się tu jednak o morderstwie człowieka w łonie matki, ale o brutalnym przerwaniu odwiecznej idei życia, przekazywanego poprzez pokolenta. Przypomina się przy tym o potrójnym rodzeniu się człowieka: pierwszym w momencie zapłodnienia, drugim w chwili wyjścia z łona matki, 1 trzecim womencie śmierci ${ }^{6}$.

Również zoroastriańska literatura religijna informuje o "niszczeniu owocu życia w łonie matki" przy pomocy środków medycznych lub mechanicznych, o winie za morderstwo spadajacej na ojca 1 matkę jak również na dostarczycielké środków aborcyjnych. W przypadku uwiedzenia i spowodowania umyślnego poronienia, szkodę za to winten wyrównać męźczyzna będący przyczyną poczęcia dziecka ${ }^{7}$. Z podobnaz postawa spotykany się takze ok. 1400 lat prz. Chr. w staroegipskich hymnach ku czci boga słońca Atona ${ }^{8}$. W żadnym jednak ze wspomnianych dotychczas źródeł wschodnich, które zdaniem uczonych oddziaływały niemało na kulturę zachodnią, nie ma mowy o zabójstwie człowieka w łonie matki, ale jedynie o winie moralnej lub o krzywdzie, którą można wyrównać materialnie.

W greckiej literaturze starozytnej pierwsze wzmianki o praktykowaniu sztucznego poronienia spotykamy w poł. $v$ w. w "Eumenidach" Ajschylosa /525-456/. Przedstawiony przez poete Apollon DelPicki odpędza od swego proroczego przybytku Erynię zalecajac jej iść do otchłani największych kaźni i męczarni, gdzie przebywaja mordercy, oszuści, trzebiciele chłopców i kobiety, które prze-

"History of Childhood Quarterly" 1/1973-1974/353-365; R.Yaron, Vitae necisque potestas, "ilevue d'histoire de droit" 30/1962/ 243-251; E.We1ss - W.Kroll, Kinderaussetzung, RE XI 1, 463-472.

6 Por. Hymns of the Atharva-Veda, transl. M.Bloomfield, in: F.Max Mellier, ed. Saciod Books of the East, Oxford 1879-1910, XLII, 165; G.Grisez, Abortion: the myths, the realities and the arguments, New York 1972, 118-121.

7 Por. Zend-Avesta, part 1: Vendîidâd,trans1. J.Darmsteter, in: F.Max Mtlier, ed. Sacred Books of the East, dz.cyt. IV, XI-XIII, LII, LIV; G.Grisez, Abortion, dz.cyt. 122 .

8 Por. Ancient Near Eastern Texts relating to the old Testament, 2, ed. James B.Pritchard, Princeton 1955, 370; G.Grisez, Abortion, dz.cyt. 123 . 
rwały ciazzę 9 . Mamy tu po raz pierwszy barwnie odmalowane piekło pogańskie, w którym za swe występki pokutują na równi z mordercami także i kobiety przerywające ciąże. Można z tego w jakimś stopniu mnioskować, że Ajschylos traktował procuratio abortus na równi z zabójstwem ${ }^{10}$. W analogicznym miejscu kaźni umieszczać bęazie tego rodzaju kobiety od ok. 135 r. równiez apokryficzna literatura chrześcijańska.

Inną interesującą wzmiankę, z tego samego niemal okresu, spotykamy $w$ jednej $z$ tragedii Eurypidesa/408-406/, gdzie Andromacha broniąc się zapewnia swego męża Menelaosa, że nie podawała jego córce żadnych środków aborcyjnych ${ }^{11}$. Szczegół ten świadczy niewątpliwie o stosowaniu juz w tym czasie, przynajmniej na dworach, środków medycznych wywołujących sztuczne poronienie, a mówi sie o nich bez zażenowania, jak o rzeczy naturalnej.

Niemniej ciekawa wreszcie informacja zawarta jest w dialogu Platona /427-347/ "Teajtet", gdzie Sokrates będący, jak wiemy, synem położnej, mówi, że akuszerki przy pomocy leków i śpiewów nie tylko ułatwiają poród, ale również wywołują u brzemiennych po-

9 Eumenides 185-190. Tekst w tym miejscu nieco uszkodzony, w związku z czym żaden z polskich przekładów J.Kasprowicza i S.Srebrnego nie uwypukla interesującego nas szczegółu. Por. tłum. S.Srebrnego /A1schylos, Tragedie, Warszawa 1954/, 450: "Wara wam od tych swiętych murów! Wasze miejsce tam, gdzie krwawe sprawuja sądy, gdzie padaja ścięte głowy, gdzie oczy wyłupiaja, gdzie

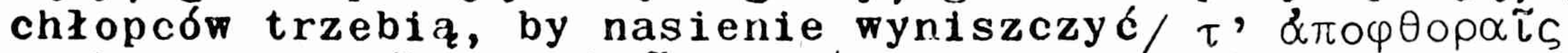

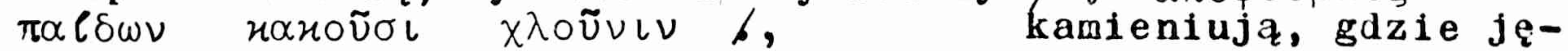
cza lamentein straszliwym na pal wbici". Tekst grecki wg Nardiego/s. 51/ moźna by przełozyć dosłownie: "gdzie się zabija dziecie w łonte matki, gdzie się praktykuje okrutną kastrację".

10 E.Nardi, dz.cyt. 49-52; F.D8lger, art.cyt. 16-18 stwierdza, ze mamy w tekście użyte wyrazente "apofthorais paidion", termin zaś "apofthora" od czasów Ilipokratesa uźywany by technicznie na oznaczenie sztucznego przerywania ciazzy.

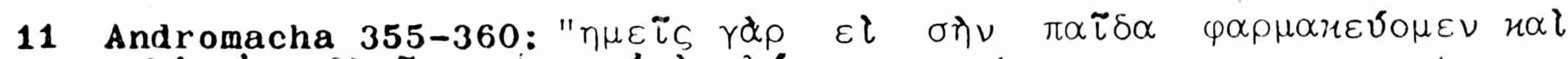

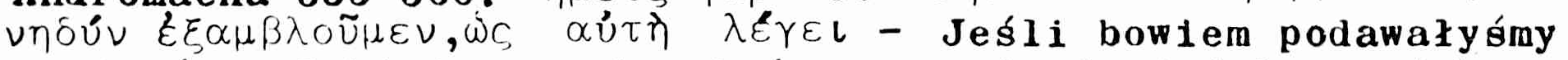
twej corce leki i spowodowałyśmy poronienie jej łona, jak sama mówi ...". Przekład J.Lanowskiego/Eurypides, Tragedie, Warszawa 1972/, 157: "Jeśli twej córce ja zadaję czary czyniąc jej łono bezpłodnym, jak twierdzisz, chętnie z ochotaz 1 nie przypadając do stóp ołtarzy, na sąd się oudaję twojego zięcia, bo mu nie mniej szkodę przynoszę jego czyniąc bezpotomny"; por. Nardi, dz.cyt. 55-56. 
ronienia ${ }^{12}$. Platon mówi o tym, jak o normalnej $i$ nie budzącej u nikogo zdziwienia zawodowej działalności połoznych. Trudno z cała pewnościa rozstrzygnać, czy tego rodzaju działalność odnosi się do sztucznego dobrowolnego poronienia, czy tez do terapeutycznego przerwania ciązy, choć kontekst zdaje się raczej wskazywać na to drugie.

0 wiele więcej informacji na temat przerywanta ciazzy dostarcza nam rzymska literatura przedchrześcijańska dwóch wioków na przełomie naszej ery. Przekazane wiadomości tego okresu są dla nas tym cenniejsze, że jego atmosfera oddziaływała bezpośrednio na rodzące się chrześcijaństwo. Spotykana zaś tutaj duża ilość wzmianek wywodzi sie nie tylko z tego, że były to czasy augustowskie - złoty okres literatury rzymskiej-ale zapewne $1 \mathrm{z}$ tego, że w tym czasie nagminnie $i$ bezkarnie stosowano przerywanie ciáży, szczególnie w sferach wyżsych.

Nasze poszukiwania informacji o przerywaniu ciaży w literaturze łacińskiej rozpoczynamy od najsławniejszego mówcy rzymskiego Marka Tuliusza Cicerona/106-43/. Wygłosił on w 66 r. prz.Chr. mowę obronną "Pro cluentio Avito" przeciw Oppianikowi, który w celu uzyskania majątku po zmarłym wuju, nie tylko zamordował kilka krewnych ośbb, ale również zapłacił jego wdowie, by spędziła pięciomiesieczny płód $i$ ten sposób zgładziła przyszłego spadkobiercę. Wdowa powodowana chciwością ulegra, dopuściła się poronienia i wyszła za Oppianika za maz ${ }^{13}$. Dla zilustrowania tego czynu Cicero

12 Teaitetus 149 cd: "Czyz nie jest prawdą, źe równieź połoźne podając leki i śpiewając piosenki, mogą wywoływać bóle, osłabiać je,jeṣli chca, oraz dokonywać trudnych porodów, a jeśli nowa istota wydaje się być bliska poronienia, dokonuja poro-

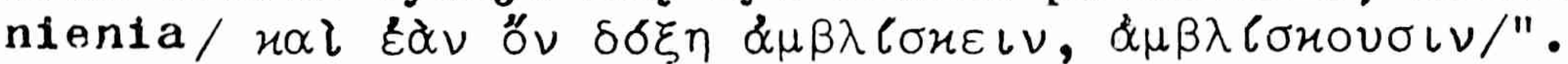

13 uratio pro Cluentio Avito 12,34, tłum. E. ilykaczewski /Mowy Marka Tuliusza Cycerona, przeł. ..., Paryż 1870, I-III/, II 44-45: "Oppianikus ... pieniazdze matce, chociaź się jeszcze nie naleźały gotowizniz wypłacił, jeśliby to wypłata zapisu, a nie nagrodiz za spędzenie płodu nazwać trzeba/si haec solutio legatorum et non merces abortionis appellanda est/. Odebrawszy tę sumo $i$ wiele innych darów, owa nadzieję, która poleconż od męża w żywocie nosiła, zdjęta chciwościaz zbrodniarzowi oppianikowi sprzedała/spem illam quam in alvo commendatari a viro continebat victa avaritia sceleri oppianici vendidit/. 
opowiada Inne podobne zdarzenie, zasłyszane podczas swej podróży do Azji Mniejszej 1 Grecj1/79-77/, o pewnej kobiecie z Miletu, która równiez przy pomocy leków dopuściła się za pieniądze analogicznego czynu, za który jednak została skazana na śmierćc ${ }^{14}$. Kontekst wskazuje, że skazano ją na śmierć nie dlatego, że dopuściła się zabójstwa, ale że zniszczyła nadzieję ojca 1 przyszłego spadkobierce. Ponadto wyrok śmierci wydano wilecie, a nie w Rymie, gdzie procuratio abortus nie było karane az tak surowo, choć nasz mówca zdaje się tego domagac ${ }^{15}$.

Najwięcej jednak wiadomości na temat przerywania ciąży w czasach augustowskich dostarczył nam Owidiusz /43 prz. Chr. - 18 p.Chr./, który poświęcił temu zagadnieniu dwie całe pieśni miłosne. Czasy panowania cesarza Augusta to okres wielkiego spokoju 1 dobrobytu, sprzyjający wygodnictwu i luksusowi, w którym sztuczne poronienia stały się po prostu modaz, nawet dla błahych powodów. Poeta skarży s1ę, że rzymskie kobiety niszczą poczęte dzieci w celu zachowanta swej urody 1 coraz rzadziej pragnz zostac matkami ${ }^{16}$. W jednym ze swoich fikcyjnych listów heroidy opowiada z sarkazmem o daremnych wysiłkach niańki, która stara się za wszelką cenę, przy pomocy róznych leków, wywarów z trawy, podkładek i czopków pomóc swej brzemiennej wychowance $w$ ukryciu jej brzucha 1 spędzeniu płodu 17 . Kry-

14 Tamźe, 11,32, kykaczewski II 44: "Przypominam sobie, ze gdy byłem $\mathbf{w z j i}$, pewna kobleta z Miletu, przekupiona przez dalszych spadkobierców, sama sobie lekami płód spędziła, za co na śmierć została skazana/partum sibi ipsa medicamentis abegisset, rei capitalis esse damnatam/. Słusznie, poniewaźzgładziła nadzleje ojca, pamiatkę jego imienia, podporę rodu, dziedzica domu, i przyszłego obywatela rzeczypospolitej/spem parent1s ... heredem familiae ... sustulisset/... Tamta kobieta własnemu ciału gwałt zadając, sama sobie była przyczyną swych cierpień/ por. Quintilianus, Institutiones oratoriae VIII 4, 11; Triphonius, Disputationum liber X, D. 48.19.39.

15 Por. Dblger, art.cyt. 39; Nardi, dz.cyt. 214-228.

16 Nux 23-24:

"Nunc uterum vitiat, quae vult formosa videri: laroque in hoc aevo est, quae velit esse parens".

17 Heroides 11,37-44:

"Iamque tumescebant vitiati pondera ventris, Aegraque furtivum menbra gravabat onus. Quas mini non herbas, quae non medicamina nutrix Attulit audaci supposuitque manu 
tykując współczesną sobie rozwiłzłość w jednej ze swych pieśni, pisze z żalem 1 gniewem również o swej kochance Korynnie, która dopuściwszy się uprzednio kilkakrotnego przerwania ciąży, teraz znów leży cięźko chora po poronieniu poczętego z nim dziecka. Mimo rozgoryczenia,prosi jednak bogów o darowanie jej życia, za co przyrzeka im solidne ofiary ${ }^{18}$. W innej znów pieśni, poświęconej w całości piętnowaniu rozpowszechnionego praktykowania poronieh, boleje nad tym, że delikatne 1 niewaleczne kobiety mordują w swoich łonach nlewinne płody po to jedynie, by nie mieć zmarszczek na brzuchu. Używają do tego kwaśnych owoców, zabójczych leków, truc1zn, a nawet wprowadzanego do wnętrza żelastwa, narażając się przez to na śmiertelne niebezpieczeństwo. Czyniąc to postępuja gorzej niż zwierzęta, bo czego by nie popełniła nawet dzika lwica czy tygrysica, tego bezkarnie dopuszczaja się delikatne dziewczęta. Gdyby tak postępowały wszystkie matki, dawno by juz wymarł cały rodzaj ludzki, a wśród zamordowanych znalazła by się zarówno sama niszcząca płód kobieta,jak i on,piętnujący te rzeczy poeta. Zauwaźa, że umierające z racji poronienia dziewczęta, odchodzaz z pogardą całego otoczenia, które nie opłakuje ich śmierci, ale powtarza, że słusznie je to spotkało. Sam jednak prosi bogów, by

Ut penitus nostris/hoc te celavimus unum/

Visceribus crescens excuteretur onus!

A) Nimium vivax admotis restitit infans

Artibus et tecto tutus ab hoste fuit!"

18 Amores II 13:

1 "Dum labefactat onus gravidi temeraria ventris,

In dubio vitae lassa Corinna iacet.

Illa quidem, clam me tantum molita pericli,

Ira digna mea; sed cadit Ira metu.

Sed tamen aut ex me conceperat, aut ego credo;

Est mihi pro facto, saepe, quod esse potest...

15 Huc adhibe vultus, et in una parce duobus;

Nam vitam dominae tu dabis, illa mihi ...

19 Tuque, laborantes utero miserata puellas, Quarum tarda latens corpora tendit onus, Lents ades, precibusque meis fave, Ilithyia:

Digna est quam iubeas muneris esse tui.

Ipse ego tura dabo fumosis candidus aris,

ipse Pero ante tuos munera vota pedes;

Adiciam titulum: SERVATA NASO CORINNA,

Tu modo fac titulo muneribusque locum. 
jeszcze raz byli dla nich łaskawi ${ }^{19}$. Objaśniając zaś w swoich "Fasti" genezę święta bogini urodzin Karpenty, opowiada o urzadzonym 214 r. przez rzymskie kobiety strajku, podczas którego dopuszczały się masowych poronien wywoływanych kłuciem jakims tępym narzędziem ${ }^{20}$. Rozżalony wreszcie, że musi przebywać na wygnaniu, wspomina w swoich "Tristiae" nieznanego nam bliżej Eubiusa, kióry mimo 1 ż równiez opisywał bezwstydne historie 1 spędzanie płodu, nie został jednak zesłany na wygnanie 21 .

Si tamen in tanto fas est monuisse timore, Hac tibi sit pugna dimicuisse satis".

19 Amores II 14:

1 "Quid luvat immunes belli cessare puellas,

Nec fera peltatas agmina velle sequi,

S1 sine Marte suis patiuntur vulnera telis, Et caecas armant in sua fata manus?

5 Quae prima instituit teneros convellere foetus, Militia fuerat digna perire sua.

Scilicet, ut careat rugarum crimine venter, Sternetur pugnae tristis arena tuae?

10 Gens hominum vitio deperitura fuit; Quique iterum iaceret, generis primordia nostri, In vacuo lapides orbe, parandus erat....

19 Tu quoque, cum posses nasci formosa, perisses,

20 Temptasset, quod tu, si tua mater opus.

Ipse ego, cum fuerim melis periturus amando,

Vidissem nullos, matre necante, dies.

Quid plenam fraudas vitem crescentibus uvis, Pomaque crudeli vellis acerba manu?

25 Sponte fluant matura sua; sine crescere nata; Est pretium parvae non levae vita korae. Vestra quid effoditis subiectis viscera telis, Et nondum natis dira venena datis?

Colchida respersam puerorum sanguine culpant,

35 Hoc neque in armeniis tigres fecere latebris, Perdere nec foetus ausa leaena suos.

At tenerae faciunt, sed non inpuno, puellae. Saepe suos utero quae necat, ipsa perit. Ipsa perit, ferturque rogo resoluta capillos,

40 Et clamant "merito", qui modo cumque vident.

Ista sed aetherias vanescant dicta per auras,

et sint ominibus pondera nulla meis.

Di faciles, pecasse semel concedite tuto;

Et satis est; poenam culpa secunda ferat".

20 Fasti I 621-624:

"Mox honor eripitur, matronaque destinat omnis.

Ingratos nulla prole novare viros.

Neve daret partus, ictu temeraria caeco

Visceribus crescens excutiebat onus".

21 Tristia II 415-416: 
Z informacji przekazanych przez Owidiusza wynika, że najczęstszą przyczyną sztucznego poronienia w jego czasach było pragnienie utrzymania piękności ciała i chęć ukrycia ciąży powstałej z relacji pozanałżeńskich. W działalności tej pomagała również często niańka. Wśród stosowanych wówczas środków aborcyjnych widzimy czopki, wywary z ziół, nieokreślone bíiżej leki 1 trucizny, oraz jakieś metalowe narzędzie. z relacji poety wynika równié, że wiele kobiet po poronieniach chorowało, a nawet umierało, nie budząc u współczesnych żadnego współczucia. Według ludu bowlem, którego opinie zdaje się podzielác równiez Owidiusz, przerwanie ciąży jest zabójstwem oraz godnyw potępienia przestępstwem i grzechem, za które naleźy przepraszać bogów 22 .

Niemniej ostro pietnował w swoich satyrach ok. 116 r.zgubną praktykz̨ przerywania ciłźy Juwenal /55-120/. Wołał on, że coraz trudniej spotkać na bogatym łoźu rodzącą kobietę, gdyż te nagminnie przy pomocy różnych sztuczek i leków przeciwdziałaja poczęciu lub za pieniądze zabijają ludzi w łonie. Hodzą tylko kobiety ubogie, bogatsze zaś wolą przestawać z eunuchami, by później nie przerywać cizży i nie stosować środków antykoncepcyjnych ${ }^{23}$. Terminologia Juwenala, podobnie jak wcześniej u Cicerona i Owidiusza, nasycona jest świadomością, że podczas przerywania ciaźy zabija się człowieka/hominem/, a nie bezkształtny płód, przez co wbrew rozpowszechnionym poglądom stolckim, uważającym płód za portio

"Nec qui descripsit corrumpi semina matrum, Eubius, impurae conditor historiae".

22 Por. Dolger, art.cyt. 40-41; Nardi, dz.cyt. 230-241.

23 Satura VI 366-368, 592-600:

"Sunt quas eunuchi inbelles ac mollia semper oscula delectent et desperatio barbae

Et quod abortivo non est opus ...

ilae tamen et partus subeunt discrimen et omnis Nutricis tolerant fortuna urgente labores; Sed iacet aurato vix ulla puerpera lecto. Tantum artes huius, tantum medicamina possunt, Quae steriles facit atque homines in ventre necandos Conducit. Gaude, infelix, atque ipse bibendum Porrige, quidquid erit, nam si, distendere vellet Et vexare uterum pueris salientibus esses Aethiopis fortasse pater". 
viscerum matris, czyn taki jest zabójstwem. Ani jednak w tym przypadku, anl w innym Pragmencie Juwenala, opowiadającym o sztucznych poronieniach płodów poczętych przez Julię z cesarzem Domicjanem /81-96/ i zakończonych jej śmiercią ${ }^{24}$, nie ma mowy o tym, by tego rodzaju praktyki były karalne lub niedozwolone ${ }^{25}$.

o tym samym wydarzeniu spędzenia płodu na dworze cesarskim pisze zarówno Pliniusz Młodszy /62-114/26, jak i Swetoniusz /70$160 / 27$. Fakt ten musiał widocznie wywołać duze wrazenie na wspó czesnych, skoro w przeciagu 20 lat wspomina go w mocnych słowach az trzech autorów. Że procuratio abortus znane było i praktykowane równiéz na dworze cesarskim, świadczy także wzmianka Tacyta /55-120/ o Neronie, który chcąc się pozbyć swej prawowitej małzonki Oktawil w celu pozyskania Poppei, oskarży já fałszywie o konspiracje, cudzołóstwo 1 spędzenie płodu, mimo iź wcześniej zarzucał jej bezpłodnośc 28 . Zarzut o spędzenie płodu nie miał zapewne w tym czasie decydujaccego znaczenia, ale obok innych rzucal dodatkowy cień na oskarżoną.

24 Satura II 29-33:

"Qualis erat nupe tragico pollutus adulter Concubitu, qui tunc leges revocabat amaras Omnibus atque ipsis Veneri Martique timendas, Cum tot abortivis fecundam Iulia vulvam Solveret et patruo similes effunderet offas".

25 Por. Dylger, art.cyt. 33-40; Nardi, dz.cyt.316-319.

26. Epistolae IV 11,6, tłum.Z.Ziółecki /Pliniusza Cecyliusza Sekunda listy przełożone ...., Wrocław 1837 /I-III/, I 305: "Zbrodnię nie mniejszaz od tej, którq karać się zdawał, popełni: potępiając o poróbstwo nieprzytomna i niewysłuchanz, a sam córke brata nie tylko kazirodztwem zmazał, lecz nawet zabił; gdyz wdową będąc wskutek poronienia umar $₫ a "$.

27 Vitae Caesarum. Domitianus 22, tłum. J.Pliszczyńska/Gajusz Swetoniusz Trankwilius, żywoty Cezarów, tłum. ...., Warszawa 1954/, 391-392: "Wkrótce po śmierci jej ojca i męża, rozmiłował sie wiej gorąco i jawnie. Sam stał się przyczyną jej śmierci, gdyż zmusił ją do usunięcia płodu, poczętego z jego przyczyny.".

28 Annales XIV 63: tłum. S.Ilammer/Tacyt, Dzieła, I-II, Warszawa 1957/, I 434-435: "Tymczasem Neron oświadcza w Edykcie, że Oktawia uwiodła prefekta w nadziei pozyskania współudziału ploty, a zapominając o tym, ze krótko przedtem zarzucił jej bezpłodność, dodaje, że w poczuciu swego wyuzdania spędziła płód, o czym on dokładne ma wiadomości; więzi więc Oktawię na wyspie Pandateril ... a wreszcie obwinienie cięzsze od wszelakiej zagłady". 
Do wymientonych łacińskich świadectw o procuratio abortus moźna jeszcze dorzucić wzmianke Plauta/250-184/ o pozbywaniu sie niepoźądanej ciaży przez hetory ${ }^{29}$ oraz opowiadanie Apulejusza z Madaury o mitologicznym nielegalnym związku Psyche z Kupidynem, których płód Wenera poleca zniszczyć, by nie narodził się bękartem ${ }^{30}$. Wenera pełni tu rolę paterfarilias 1 mówi o przerwantu ciązy jak o rzeczy najbardziej naturalnej, co oddawało dobrze ducha II w., panującego szczególnie w sferach wyższych.

Na tle tego ogólnego zepsucia 1 dowolnego przelewania krwi nie narodzonych dzieci szczególnie pięknie brzmia słowa Seneki /5-65/ skierowane do swej matki Helwil, której gratuluje, że mbrew zwyczajom innych kobiet, ona nie wstydziza sie ani posiadania wielu dzleci, ani brzemiennego łona i nigdy nie zniszczyła poczetego potomstwa 31 .

Na kształtowanie starożytnych poglądów etycznych, szczegó1nie sferach wyższych, w duzym stopniu wpływała 1110 z I $\mathbf{i}$, a zwłaszcza jej trzy kierunki: platonizm, arystotelizm 1 stoicyzm. Trzeba jednak na wstępie zaznaczyć, że problemem przerywania ciązy filozofia grecko-rzymska zajęła się stosunkowo póńno. Powodem zaś tego był lakt, że ogół przedsokratyków nie uznawał płodu za istote oźyionaz przez dusz̨, a w zwiłzku z tym jego zniszczenia nie uważano za zabójstwo.

29 Truculentus 201-203, tłum.G.Przychocki /T.H.Plautus, Komedie I-IV, Kraków 1931-1937/, III 412: "Kryła się i bała, żebyś ty jej nie namówił do spędzenia płodu, żeby dziecko uśmierci$1 a^{\prime \prime}$.

30 Metamorphoseon VI 9: "Małżeństwo to nie może być uznane za prawe; urodzi się z niego bękart, jeśll pozwolimy ci donosić do końca tę ciążę".

31 De consolatione ad Helviam 16,3, tium. L.Joachimowicz/L.A. Seneka, Pisma Pilozoficzne I-III, Warszawa 1965/, I 529: "Nigdy nie wstydziłaś oię swego licznego potomstwa, jak gdyby miało niekorzystnie swiadczyć o twoim wieku. Nigdy zwyczajem innych kobiet, które szukaja chwały w swoich kształtach, nie ukrywałaś ciężarnego łona, jak gdyby nieprzyzwoitego brzemienia, ani nie udaremniłaś poczętych w swoich nętrznościach nadziei potomstwa/nec intra viscera tua conceptas spes liberorum elisisti/". 
Platon /427-347/ uczac o swym ldealnym państwie, przewidywał w nim równiez ustalona liczbę dzieci, o której winny decydować władze najwyżzze. Wspomina takż, iż jest wiele sposobów na zwiększanie lub zmniejszanie rozrodczości ${ }^{32}$, choć o zadnym z nich konkretnie nie mówi. Kobiety winny rodzić w wieku 20-40 lat. Poza tym okresem rozpłodu, kobieta $i$ mężczyzna winni się starać, by nie doprowadzać do poczęcia i nie rodzić nowych dzieci. Jeśliby zaś mimo tego któraś kobieta zaszła w ciążę, to taki płód albo należy poronić przed narodzeniem, albo porzucié po narodzeniu ${ }^{33}$. Tego rodzaju okrutny stosunek do późno poczętego życia podyktowany by dobrem państwa, ze względu na które platon zezwalał zarówno na antykoncepcje, jak i na przerywanie ciaży i porzucanie noworodków ${ }^{34}$, Zalecenia Platona dotyczace niszczenia późno poczętych płodów będa później zwalczać Euzebiusz z Cezarei ${ }^{35}$ i Teodoret z Cyru ${ }^{36}$.

32 Leges V 740 d, tłum. M.Maykowska /Platon, Prawa, Warszawa 1960/, 198: "We wszystkich tych wypadkach najwyższa nasza 1 najdostojniejsza wadza będzie musiała rozważý, co trzeba zrobić, gdy jest zbyt wielka lub zbyt mała ilosć dzieci, i znaleźc sposób, żeby utrzymała się niezmiennie owa liczba pięciu tysięcy czterdziestu domów. Sposobów jest wiele, bo moźna 1 na zmniejszenie się płodności wpływać, jeżeli jest zbyt obfita, 1 odwrotnie, na zwięsszenie się liczby urodzin".

33 Respublica V 9,461 bc, tłum. W. Witwicki/Platona państwo, Warszawa 1948/, I 257: "Kobiety i mężczýni poza latami rozpłodu ... będę mieli rozkaz starać się, żeby najlepiej ani jeden owoc takiego stosunku nie ujrzał światła dziennego jeśliby

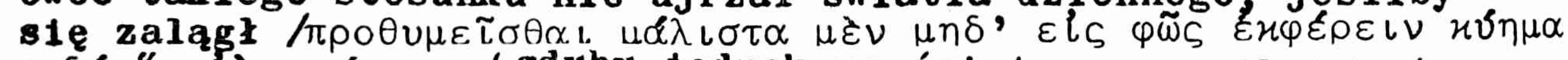

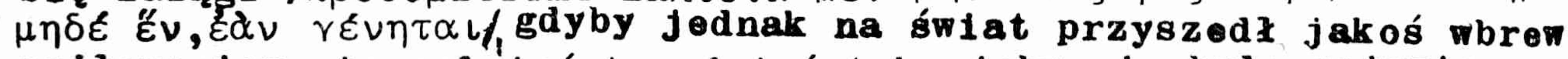
usiłowaniom, to połozyć to gdzieś tak, zeby nie było pozywienia dla niego". por. D8lger, art.cyt. 7; Nardi, dz.cyt. 116122.

34 Tamze, 460 b, s.255: "Dziec1 tych gorszych, gdyby sie tym innym jakies ułomne urodziło, to tez w jakimśmiejscu, oktorym sie nie mówi i nie bardzo wiadomo, gdzie by ono było, ukryć jak nalezy".

35 Por. Praeparatio Evangelica XIII 19, GCS 43, 249, 17-18.

36 Graecarum affectionum curatio V 52, PG 83, 941. 
Nurtuje nas tu pytanie, czy twórca Akademil uwazal płód za lstotę zywą, a jeśl1 tak, to od jakiego momentu? Nie znajdziemy u niego na to żadnej odpowiedzi, choć póńniej Tertulian będzie go zaliczał do filozofów uczących, iz dusza łaczy się z ciałem podczas narodzin 37 .

¿ównieź Arystoteles/384-322/ poruszal problem prokreacji widealnym państwie 1 zajmowaz się ograniczaniem liczby dzieci. W przeciwieństwie jednak do Platona nie proponuje porzucania noworodkóm ze względu na nie pozmalajace na to obyczajesale zaleca tylko prewencyjne spędzanie płodów poczętych ponad ustaloną liczbę. Zeby jednak takie poronienie mogło być dopuszczalne 1 godziwe, musi być przeprowadzone na początku ciązy, zanim płód zostanie ozywiony; później bowien, kiedy płód ma już czucie i zycie, tego rodzaju sztuczne poronienie jest niegodziwe 1 niedopuszczalne ${ }^{38}$, bo może być zabójstwem, choć Stagiryta nigdzie o tym nie mów1.W zyciu płodu rozrózniał on dwa okresy: stadium nieoźywienia i oźywionia. Ulegajac wpływom znanych starożytnych lekarzy Dioklesa z Karystos /IV w./ 1 Hippokratesa z Kos /460-367/ przyjmował, że embrion męski jest ozywiony $i$ posiada czucie juz po 40 dniach od swego poczęcia, żeński natomiast po 90 dniach od poczęcia ${ }^{39}$. Przod tymi

37 De anima 25,2, CCL 2,819.

38 Pol1tica VII 14,10,1335 v, tłum. L.Piotrowicz/Arystoteles, Polityka, Warszawa 1964/, 331: "W kwestii usuwania czy wychowywania noworodkow winno obowizzywać prawo, by nie wychowywac zadnego dziecka wykazujacego kalectwo. Biorąc jednak pod urage liczbe dzieci, nalezy wobec tego, że istniejace obyczaje nie pozwalaja usuwac żadnego noworodka, liczbę urodzin prawem ograniczyé; jeśli zaś jacyś obcujący ze sobą małzonkowie poczną dzlecko ponad te liczbz, nalezy spowodowá jego poronienio,

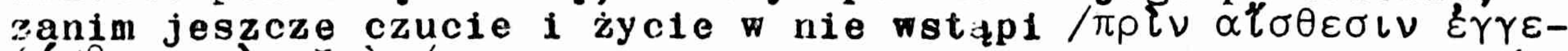

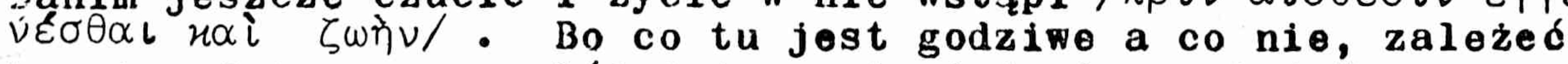
bęarie od tego, czy płód już czucie i życie posiada"; por. Dolger, art.cyt. 7-9; Nardi, dz.cyt. 123-132.

39 Historia animalium VII 3,583 b, tłum. P.Siwek/Arystoteles, Zoologia, Warszawa 1982/, s.288: "Gdy chodzi o embriony płci męskiej, ich ruch wyczuwa się zazwyczaj na boku prawym, po upływie mniej więcej czterdziestu dni /por. Hippokrates, Aphor. V 48/; gdy chodzi o embriony płci żeńskiej, na boku lewym okoto dzlewięćdziesiątego dnia. Nie należy jednak brać zadnej z tych wskazówek dosłownie ... W tym mniej więcej czasie embrion zaczyna sie różnicować; przedtem tworzył masę ciała niezróżnicowaniz. Nazywaja "upływem" poronienie płodu, które zachodzi 
dniami ożywienia są one bezkształtna masa 1 ich poronienie jest dopuszczalne. Potwierdzając życie płodu męskiego po 40, a żeń-

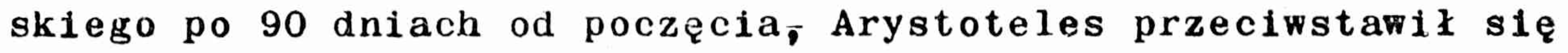
rozpowszechnionernu poglądowi filozoficznemu Empedoklesa/495-415/40 1 reprezentowanemu przez współczesnego mu Diogenesa z Sinope /403$-323 /^{41}$, którzy uczyli, że dusza wchodzi w płód dopiero womencie rodzenia się człowieka. Do tego zaś momentu płód przez cały czas jest istotą nieoźywioną. Zasygnalizowane po raz pierwszy waszych rozważaniach rozróżnienie płodu ożywionego i nieożywionego będzle się jeszcze długo przez wieki powtarzać, zarówno u autorów pogańskich, jak i chrześcijańskich.

Szczególny wpływ na prawodawstwo rzymskie i starożytne poglądy etyczne wywierał stoicyzm, głoszący hasło, że mędrzec winien

w ciagu pierwszych siedmiu dni /po poczęciu/, a "wydalentem" poronienie płodu, które ma miejsce okresie późntejszym aź do czterdziestego dnia. Poroniente ma miejsce szczególnie w tym czterdziestodniowym okresie. Jeśli embrion wydalony w czterdziestym dniu jest płci męskiej, rozkłada się zupełnie i znika, gdy się go zanurzy w jakimkolwiek płynie; lecz gdy się go zanurzy w wodzie zinnej, stanowi rodzaj masy w błonie; gdy sie błonę raz rozedrze, zjawia się embrion wielkości olbrzymiej mrówki: widać dobrze jego członki, tak jak wszystkie inne organy łącznie z członkiem męskim; również oczy jego są, jak u wszystkich innych zwierząt, niepospolicie wielkie. Embrion żeński poroniony w trzech pierwszych miesiazcach wyglaqda przeważnie na mase niezróżnicowaną. Jeśli embrion przekroczył czwarty miesiąc, jego części saz dobrze dostrzegalne i szybko postępuje ich różnicowanie. Zatem aż do urodzenia embrion żeński dochodzi do mykończenia swoich części powolniej niż embrion męski; dziewczynki rodzą się częściej niź chłopcy po dziesięciu miesiącach brzemienności".

40 Por. PsPlutarchus, De placitis philosophorum V 15: "Empedokles uczy, że embrion nie jest bytem żywym, ale w jakiś sposób oddycha w łonie. Jako istota żywa oddycha po raz pierwszy w momencie rodzenia się, przez wprowadzenie powietrza z zewnątrz do otwartych naczyń"; XXVI 4: "tak drzewa sa czésiami ziemi, jak płody w łonie sa częściami macicy".

41 Por. PsPlutarchus, De placttis philosophorum V 15,4; "Diogenes mówi, ze płody rodzą się nieożywione ale ciepłe. Posiadający naturalne ciepło urodzony płód wchłania zaraz w płuca zimno /duszę/. 
1ść za prawami natury. Każdy normalny człowiek winien sie ożenić i w ten sposób zapewnić prokreacje. Małżeństwo i współżycie wykluczające prokreację jest nieważne i niedopuszczalne.W swych poglądach dotyczacych rozwoju embrionalnego stoicy szli za nauka Empedoklesa 1 Diogenesa głosząc, że płód przed narodzeniem jest tylko częścia wnętrzności matki - pars viscerum matris, podobnie jak drzewa są częściami ziemi; jest bytem nieożywionyn, który dopiero w momencie narodzenia otrzymuje życie i duszę. Zenon z Kitionu /336-264/ lubił porównywać płód do owocu rośliny, który dojrzewa 1 odpada 42. Naukę stoicka w wielu tezach uzupełnił 1 rozwinał Chryzyp z Solo1 /280-205/, w sądach jednak o płodzie podtrzymywał tylko poglądy swych poprzedników ${ }^{43}$. W tak rozumianym systemie filozopicznym nie było więc miejsca na strawianie problemu godziwości lub niegodziwości przerywania ciaży. Sztuczne spędzanie płodu, niezaleźnie od tego, z jakich powodów się odbywało, przy takich założeniach filozoficznych nie mogło pociłgać za sobą ani poczucia winy ani oskarżenia - zabójstwo ${ }^{44}$. Z naukaz stoickaz dotyczzcą szczególnie momentu ożywiania płodu, będą polewizować autorzy chrześcijańscy, jak np. Tertulian 1 Laktancjusz ${ }^{45}$.

Latwo zauważyć, że stoickie poglądy o płodzie przeciwstawiały sie nauce Hipokratesa $i$ Arystotelesa, co prowadziło do długich 1 niekończących się dyskusji na temat, czy płód jest istotą żywą. Tak np. dużą popularnościa cteszyła się w starożytności przypisywana Lizjászowi /445-378/ mowa "De abortu", w której autor zastanawia się, czy $i$ od Jakiego momentu embrion jest człowiekiem 46 czy naleźy

42 Por. PsPlutarchus, De placitis philosophorum V 15,2: "Stoicy uczą, że płód jest częścią macicy, a nie bytem żywym / $\mu \varepsilon \rho \circ \varsigma$

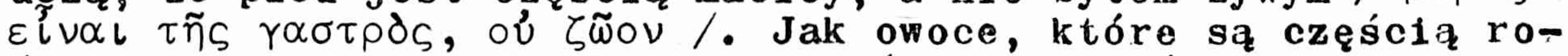
bliny dojrzewaja i odpadają, tak również i płód".

43 Por. Plutarchus, De stolcorum repugnantiis 41,1: "/Chryzyp/ głosi, że płód jest jak roślina w łonie matki. Kiedy się urodzi i orzeźwi powietrzem, staje się bytem źywym. Stąd to nazwa duszy wywodzi sie od oddechu".

44 Por. Nardi, dz.cyt. 154-159, 206-213.

45 Por. Tertullianus. De anima 25,2; Lactantius, De opificio Dei 17,6 .

46 Wspomina o niej pod koniec I w. Theon, Progymnasmata 2,14, w latach 166-176 Onomastikon Polluksa oraz Lexicon decem oratorum Harpokrationa. 
staw lac przed sądem kobiety dopuszczające się przerywania ciaży. Na pytania te odpowiada twierdząco głosząc, że przerwanio ciązy jest zabójstwem człowleka, co roga potwierdzić zarówno położne, jak 1 praktyka lokarska. Nadal jednak dyskutowano wśród prawników, retorów i filozofów nad tym, czy faktycznie sztuczne poronienie jest zabójstwem, lub dlaczogo płód 6-miesięczny nie może żyć, a urodzony w siódmym lub dziewiątym miesiacu żyje ${ }^{47}$. Wszystkie te dyskusje prowadziły powoli do krystalizowania sie przekonania, że rozmyślne znıszczenie płodu, niezaleźnie od jego wieku, jest zabójstwem lub przynajmniej działaniem wysoce niemoralnym. Jeżeli chodzi o s t o s u n e $k$ s t a $r$ o ż y $t$ n e g o p r a a do procuratio abortus, to był on zróżnicowany Prawodawstwo wschodnie od swego zarania przewidywało kary za spowodowanie poronienia przez drugą osobe u brzemiennej, nie wspomina natomiast o tego rodzaju dzlałalności przez same matki. Tak więc spowodowanie poronienia uderzeniem brzemiennej przez aruga osobe karał już Kodeks Hammurabiego z lat 1955-1913 prz.Chr. ${ }^{48}$, stare prawo asyryjskie z ok. 1600 roku prz.Chr. ${ }^{49}$, oraz prawo hetyckie z okresu 1300-1250 roku prz.Chr. ${ }^{50}$, które niewatpliwie zaciążły

47 Por. Prolegomena ton staseon, Rhetores graeci, ed. Waltz, VII, 15-16; Nard1, 82-93, 567-569.

48 Por. W.Eilers, Die Gesetzesstelle Chammurabis = "Der Alte Orient" 31/1932/, Heft 3/4, 46-47. Tłumaczę z niemieckiego, Dølger 4: "Jeśliby obywatel uderzył córke drugiego obywatela, a ta wskutek tego poroniła, to za jej płód zapłaci 10 syklów srebra. Jeśliby zaś ta kobieta zmarła, winno się zabić jego córke. Jeśliby któs spowodowal przez uderzenie utratę płodu u corki poddanego, to zapłaci 5 sykli srebra, a gdyby ta kobieta zmarła, zapłaci pół miny srebra. Jeśliby on uderzył niewolnicę obywatela, a ta poroniła, to zapłaci 2 sykle srebra; gdyby zaś ta niewoinica zmarła, zapłaci pół miny srebra".

49 Por. A.Jirku, Altorientalischer Kommentar, zum Alten Testament, Leipzig-Erlangen 1923, 95. Tłumacze z niemieckiego, Dolger 4: "Jeśli mężczyzna uderzył córkę kogoś drugiego i spowodował u niej poronienie, to winno mu sie ten czyn udowodnić przez świadków, on zaś winien zapłacić 2 talenty, $30 \mathrm{~min}$ ołowiu, otrzymać 50 kijów oraz spędzić miesiąc czasu na służbie u króla".

50 Por. H.Zimmern - J.Friedrich, Hethitische Gesetze aus dem Staatsarchiv von Boghazkoi = "Der Alte Orient" 23/1922/, 2,8. Tłumaczę z niemieckiego, Dolger 5: "Jeśli ktoś spędzi płód wolnej koblecie, to gdy to był płád 10-miesięczny, zapłaci 10 
w nlemaxym stopniu na analogicznych przepisach Prawa Mojżeszowego /Wj 21,22-23/. We wszystkich powyzszych przypadkach prawo traktowało nie narodzony płód jako rzecz,której zniszczenie można pyrównać lub wynagrodzić pewną sumą pientędzy, pracą, lub w Inny materialny sposób. Nie ma wich mowy o tym, ż płód jest istotą zywą, Lającą prawo do życia, którego zniszczenie pociąga za sobą sankcje karne. Płód jest własnością pana, do którego brzemienna naleźy, i któremu należy wyrómnać krzywdę za jego zniszczenie. Na uwage zasługuje tu tylko zaznaczone w prawle hetyckim rozrózniente wleku płodu: im płód był starszy 1 bardzlej ukształtowany。 tym większa szkodą było jego zniszczenie, wymagajace tym mięsszego wyrównania materialnego 51 .

Czy prawo greckie karalo przerywanie claży, zdania sa podzielone. Przyjmujacy takie prawo karne ${ }^{52}$, powołuja sie juz na Arystotelesa, który uwaźał za rzecz nlegodziwa zniszczenie płodu posiladającego czucie i życie ${ }^{53}$. Dla F.Dulgera zdanie tego Pilozora stanowi wystarczający dowód na istnienie Grecji prawa zabraniającego przerywania ciłży, przynajmniej zaawansowanej 54 . Prawo takie, zdaniem zyjącego pod koniec II w. po Chr. Pseudo-Galena, autora rozprawy "Czy płód jest istota zywą" mial juz wydać 1egendarny król Sparty Likurg/VIII $w_{\bullet} /$ i aterisici prawodawca Solon /640-559/, którzy, zdaniem pisarza, nie wyznaczaliby kary za sz⿺uczne poronienie, gdyby nie uwazali płodu za istote zywas. In ${ }^{55}$.

sykl1 srebra, gdy zaś by 1 -mieslęczny, musi zaplacié 5 sykil srebra; rtedy dopiero gładzi on swa winę Jeśl1 ktoś spegdzi płód niewolnicy, to gdy to by 1 płód 10-miesieczny, musi zapłacić 5 sykl1 srebra".

51 Dolger 5.

52 Np. E.Caillemer, Ambloseos graphé, DAG I, $1,225$.

53 Por. note 38 .

54 D81ger 10 .

55 An animal sit id, quod in utero est 5, Medicorun graecorua opera quae exstant, Claudi Galeni opera omnla, $\theta d$. C, Gottiob Känn, t.XIX, Lipsiae 1830, 178. Tekst grecki przytacza Nard 34-35: "To co sie znajdujo w gebi kona, jest letota zywa... Teraz zas przy pomocy prew i okolicznosej udowodnimy, ze ombriony są bytami zywymi ... Wydano prawa, a wśród nich dwa bardzo waźne dowodza, ze byty wonio sa istotami zy wymi: z jednej strony przez nazozente kary na winnogo przermania clazy, dru giej zaś przez zezwolente, by jeazcze nie urodzeni mogli wostać spadkobiercami ... Ich wiec uczniow 1e, prawodawcy Likurg 
macja ta jest jednak zbyt ogólna i nic nie mówi ani o okolicznośclach ani o wymiarze kary. Nie mamy żadnych innych źródłowych danych na temat ustalonych prawnie przez Likurga kar na przerywajacych ciazżę, choć niektórzy powołujaz się jeszcze w tym względzle na plutarchowy żywot tego króla. Jest tam bowiem informacja, że odwodzil on od spędzenia płodu majz̨cą byé jego żoną brzemienną wdowę po bracie, by nie narażała życia na niebezpleczeństwo ${ }^{56}$. Nie ma tu jednak mowy o jakimś istniejacym prawie przeciw aborcjonistom, a zasadniczym powodem zaniechania planowanego poronienia nie była wcale chęć ocalenia życia dziecka, które i tak miano porzucić, ale obawa przed mogazcą wyniknazć z poronienia utratą zdrowia. Owszem, wzaianka ta świadczy, że sztuczne poronienia niewygodnych dzieci praktykowane było przez Spartanki nawet na dworach. Likurg mógł osobiście potępiać przerywanie ciaży, ale z tego nie wynika, że wydał on jakieś konkretne prawo przeciwaborcyjne.

Na podstawie dwóch powyźszych źródeł nie można więc z całą pewnościa strierdzić istnienia prawa przeciwaborcyjnego, wydanego

I Solon, przez te dwa wymienione rozdziały dostarczyli nam bardzo mocnego dowodu o embrionach. Gayby one nie były bytami żywymi, ci prawodawcy nie nakładaliby prawnie sankcji karząc zde-

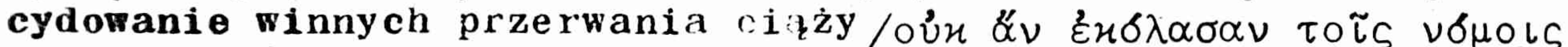

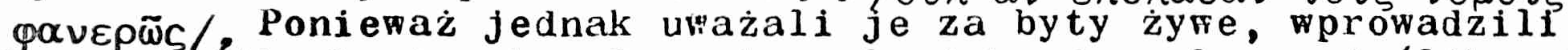
karę. Któżby bowiem karał za to człowieka dorosłego, jeśliby nie uznawał, że to co jest w łonie, jest człowiekiem i czymś źywym

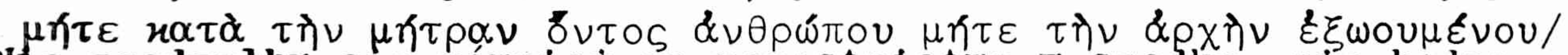
Nie zgadzałby się również na uczestnictwo w spadku, nie będz̨c przekonany, że embrion jest byten żywym. Któż bowiem bierze na spadkobierce kogoś, odnośnie którego miałby watpliwości, czy już istnieje"; Dolger 10; Nardi 33-38.

56 Plutarchus, Vitae. Lycurgos 3-4: "Gdy kobieta poleciła dyskretnie rozglaszać i sama rozpowiadała, że chce zniszczyé płód, aby razem $z$ nin zostać królowa Sparty, on nie pochwalał jej planu, choć wamej rozmowie nie zaprzeczał, a udajazc aprobację 1 akceptacje mówil, że nie powinna przez poronienie i branie środków aborcyjnych niszczyé swego ciała i naraźać się na niebezpieczeństwo. Sam bowiem zamierzał urodzone dziecko natychmiast oddalić. Oszukując w ten sposób kobietę aź do porodu, gdy się dowiedział, ze rodziła, posłał do niej strózów i opiekunów"; Dolger 11-12; Nardi 39-41. 
przez Likurga, a jak twierdzi E.Nardi, takiego prawa nie było w Grecj1 do końca IV w. prz. Chrystusem ${ }^{57}$. Tego rodzaju prawo istniało, jak słyszeliśmy od Cycerona, pod koniec republiki na greckich terenach Małej Azji ${ }^{58}$. Trudno jednak powiedzieć, czy to było prawo greckie czy azjatyckie, które pomijając motywy, karało sztuczne poronienie jak zabójstwo. Jeżeliby nawet w Grecji istniały takie prawa, to jak chyba słusznie zauważa F.Dølger, nie wypływałyby one z założeń religijnych czy pobudek etycznych, ale przede wszystim z ludnościowej polityki państwa ${ }^{59}$. Zdanie to potwierdza wakimś stopniu Informacja z końca I w.p.Chr., przekazana przez Muzoniusza Rufusa, autora rozprawy "Czy wszystkie dzieci maja być chowane", w której jest równiez mowa o prawnym zakazie przerywania ciaży $i$ o karach za tego rodzaju przestępstwo 60 . I tu jednak powodem tych praw nie było dobro 1 zycie dziecka, ale czysto stoicki argument dobro ogółu i społeczeństwa. Prawo to miało zabraniać sterylizacjis przerywania ciąży $i$ antykoncepcji, trzech wykroczeń postawionych na tym samym poziomie, których karanie świadczy o planowej polityce ludnościowej. Chociaz nie wiemy, kto tego rodzaju prawa promulgował, to jednak warte jest podkreślenia, że problemem tym zajęło się państwo.

Możha tu jeszcze wspomnieć za F.Dbigerem pewne przedchrześciJańskie prawo egipskie, które zabraniało wykonywania wyroku na skazanej na śmierć brzemiennej, dopóki nie porodzi. Wspomina o nim Dio-

$57 \quad$ Nardi 41.

58 Por. note 14 .

59 Dølger 13.

60 Musonius, Fragmentum XVa, ed. 0.ilense, Berolini 1909, 77: "Prawodawcy, którzy riaj z za zadanic czuwać i szukać tego, co dla państwa jest dobre a co złe, lub co społeczeństwu przynosi korzyść a co szkodę, czyż nie będa uwaźać za rzecz pożytecznz dla państwa, jeśli zwiększa się liczba domów obywatelskich, lub za rzecz szkodliwi, jeśli się ona zmniejsza? Czy nie usazaja bezdzietności lub posiadania zbyt małej liczby dzieci za rzecz szkodliwa, a posiadanie ich, na leusa, jak najwięcej za rzecz pożyteczniz. Ten właśnie wzgl żd zabronił kobietom przerywać cizżę, a na nieposłuszne nakładaí kary, /

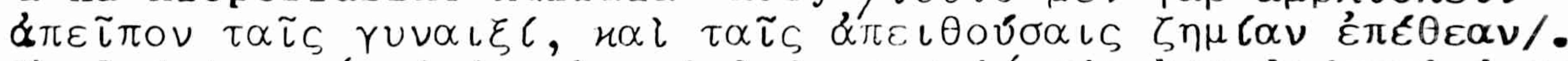
Wzglizd ten również zabraniał im czyníc si? bezpłodnymi i przeszkadzać poc'zaciu, w wy padku zaś licznego notonstwa ustanowili nasrody dla męzczyzny i kobiety, a bezizietnośc uznali za karalna"; 
dor Sycylijczyk z czasów Cezara ${ }^{61}$. W prawie týn mówi się o dwojgu: winnej matce i niewinnym, nie posiadającym jeszcze żadnej św1adomości dziecku, które nie moga ponosić jednakowej kary. Płód nazwany jest w nim, bez określania stadium rozwoju, dzieckiem, stawianym na równi z dorosłym człowiekiem, którego nie wolno zabijać. Podobne prawa, zabraniające egzekucji na brzemienrych, dopóki nie porodza, znane były równiez u Greków i Bzymian 62 .

Jeśli chodzi o prawodawstwo rzymskie, to na konkretne prawa skierowane przeciw spędzaniu płodu trzeba poczekać aź do początków

Nard1 12-16; D8lger 14.

61 Diodor Siculus, Bibliotheca historica I, 77,9, rec. F.Vogel, Lipsiae 1888, 131. Tłumacze z greckiego tekstu u Nardiego 225226, n.53: "Kobiety skazane na śmieré, jeżeli są brzemienne, nie powinny być tracone, dopóki nie porodza. Zasade tę wprowadziło wielu spośród Greków, uważając, że byłoby absolutnie niesprawiedliwe, żeby niewinne musiało ponosić te sama karę co winna, i zeby za przestępstwo jednej, wymagano kary dla dwojga $\tau \circlearrowright$

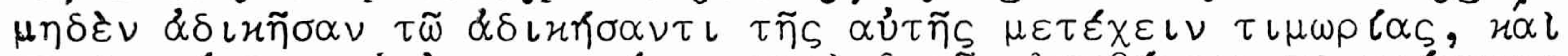

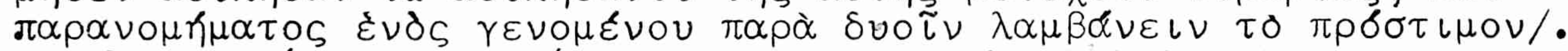
Byłaby to równieź obraźliwa decyzja, gdyby istotę nie posiadająca jeszcze żadnej świalomości poldawano tej samej karze. I rzecz najwaźniejsza ze wszystkich, żeby tylko brzemiennym wymierzano kare, a nie niszczono dziecka/teknon/, będącego własnościz wspóiną ojca i matki. Jak bowiera za złych sędziów trzeba uznać takich, którzy uniewinniaja sprawcę nordu, tak również za złych sędziów musi się uznać takich, którzy zabijają całkiem niewinnego".

62 Por. F.D8lger, Tertullian uber die Blauttaufe, ACh 2/1930/ 131, n.47. Prawo to według Plutarcha/De sera numinis vindicta 7 , 552d/ znane było najpierw u Egipcjan, później zaś przejall je równiez Grecy i Rzymianie. Można tu wskazaé kilka przykładów, np. Aelianus, Varia historia V 18: "Niewinny płód wyłazczali od potępienia, sama winna była skazywana na śmierć"; Philo Alexandrinus, De virtutibus 18,139: "Prawo nakazuje wstrzymać egzekucje na brzemiennych winnych śmierci, dopóki nie porodza, aby nie niszczyć zawartości łona"; Quintylianus, Declanatio 277: "Prawo poleca odłożyć wykonanie wyroku śnierci na brzemiennej az do dnia porodu"; Ulpianus, 1.3 de pocnis: "Praegnantis mulieris consumendae damnatae poena differtur, quoad pariat. Ego quidem, et ne quaestio de ea habeatur, scio observari, quamdiu praegnans est"; Tak równiez odłożono egzekucję b̧̨dącej w wiz̨zieniu w 8-miesiazcu cizży św. Perpetui, aż porodzi, "quia non licet praegnantes poena repraesentari" /Passio Perpetuae 16,2/; Clemens Alexandrinus, Stronateis II 18,93,2: "izynianie postanowili, źe kiedy kobieta w brzemiennym stanie skazana zostanie na śmierć, żeby nie wcześniej wykonano wyrok, aź porodzi". 
III wieku. Zasadniczym zaś tego powodem zdaje się być wspominany Juz przemożny wpływ stoicyzmu na prawo rzymskie,które nie urodzonego płodu nie uwaźło za człowieka ${ }^{63}$, ale za część wnętrzności matki ${ }^{64}$, a nawet za istotę niezywa - nondum animal ${ }^{65}$, traktowanaz nie werze rzeczy ludzkich 66 , ale materialnych. W konsekwencj 1 takiej postawy, za człowieka uważano prawie dopiero dziecko urodzone, które mogło zostać spadkobierca, choćby nawet było sztucznie wydobyte żywe z łona umierającej matki ${ }^{67}$; zniszczenia zaś płodu przez procuratio abortus nie uważano za morderstwo ${ }^{68}$. Tak teź postępowano $w$ praktyce prawnej przez całe wieki, chociaz Plutarch już Romulusowi przypisywał wydanie prawa zabraniajacego przerywania ciazy $i$ zezwalającego męzowi na porzucenie żony, jeśli ta wbrew jego moli uzywała trucizny w celach aborcyjnych ${ }^{69}$. Choć sam tekst jest uszkodzony, bardzo niejasny i budzacy dyskusje, to jest jednak faktem,ze rzymskie prawodawstwo juz wcześnte uwazało zabicie płodu za

63 Digesta 35.2.9.1: "Papinianus libro nono decimo quaestionum: circa ventrem ancillae nulla temporis admissa distinctio est, nec Immerito, quia partus nondum editus, homo non recte fuisse dicitur".

64 Digesta 25.4.1.1: "... partus enim antequam edatur, mulieris portio est vel viscerum".

65 Digesta 38.8 .1 .8 .

66 Por. Digesta 37.9.7. 1 28.6.10.1.

67 Digesta 28.2.12: "Ulpianus libro nono ad Sabinum: Quid dicitur Pilium natum rumpere testamentum, natum accipe et si exsecto ventre editus sit: nam et hic rupit testamentum, scilicet si nascatur in potestate. Quid tamen, si non integrum animal editum sit, cum spiritu tamen, an adhuc testamentum rumpat? Et tamen rumpit".

68 Por. G.Humbert, Abortio, DAGR I, 1, 9-10; tenze, Abigere partum, DAGR I, 1,7-8; Hartmann, Abortio, aE I, 1,108.

69 Vitae. Romulus 22, 3: "/Romulus/ wydał takze pewne prawa, z których cięzsze jest to, że nie pozwalał kobiecie opuszczać męza, męzowi natomiast pozwoliz porzucić żonez zowodu trucizny przeciw dzleciom, podrzucenia kluczy 1 cudzołóstwa". Interesujący nas tekst jest niejasny 1 bardzo dyskusyjny/Nardi 16-29/. F.D\&lger pisze:"W greckim tekście stoi wprawdzie tylko éti $\varphi \alpha \rho-$ $\mu \alpha \varkappa \varepsilon l \alpha \tau \xi \mathcal{H} \nu \omega \nu$. Nie oznacza tu jednak trucia żyjacych dziec1, ale uzycie trucizny w celu spędzenia płodu" /s.38/. 
niemałe wykroczenie, skoro zezwalało za nie porzucić żonę. I w tym przypadku nie chodziło o wykroczenie przeciw zyciu nie narodzonego dziecka, ale o przestępstwo przeciw obowiazzom zony, która męzoni winna rodzić dzieci ${ }^{70}$.

Do czasów królewskich odnosili także rzymscy prawnicy zakaz grzebania zmarłej brzemiennej kobiety, dopóki nie wydobędzie sie z jej łona płodu, będącego nadzieją zycla, a który by zginął wraz ze $\operatorname{mar} \mathfrak{z}^{71}$.

o jakichkolwiek sankcjach za przerywanie ciąży nie wspominają równiez dwa słynne prawa z I wieku prz.Chr. przeciw mordercom: z $81 \mathrm{r}$. Lex Cornelia de sicariis et veneficis, i z 55 r. lex Pompeia de parricidís, choć od czasów małzeńskich reform cesarza Augusta ${ }^{72}$ pierwsze z nich zaczęto stosowaé do wytwarzajacych 1 rozprowadzajacych árodki aborcyjne ${ }^{73}$. Płód nadal był traktowany przez prawników, szczególnie gdy chodziło o sprany dziedziczenia, jako spes ${ }^{74}$, lub jako spes dubia hominis ${ }^{75}$. W praktyce prawniczej stosowano równiez od wieków zasadę wspomnianá przez Plutarcha ${ }^{76}$, źe jeżeli żona wbrew woll męża dopuści się poronienia, to on ma prawo nie tylko do dania

70 D81ger 38.

71 Digesta 11,8.2: "Marcellus libro vicesimo octavo digestionum: Negat lex regia mulierem, quae praegnans mortua sit, humari. antequam partus ei excidatur; qui contra fecerit spem animantis cum gravida peremisse videtur".

72 Por. Lex Iulla de maritandis ordinibus z 18 roku prz.Chr. oraz Lex Papia Poppaea z 9 roku po Chrystusie.

73 Digesta 48.8.3: "Eiusdem legis Corneliae de sicarils et veneficis capite quinto, qui venenum necandi hominis causa fecerit, vel vendiderit vel habuerit plectitur"; 48.8.1.1: "Praeterea tenetur qui hominis necandi causa venenum confecerit dederit".

74 Por. Cicero, Pro Cluentio 11,32: "spem parentis" = nota 14; Seneca, Ad Ielviam 16,3: "spes liberorum" = nota 31; D1gesta 11.8.2: "spem animantis" = nota 71; Iustiniani Institutiones 2,13,1: "... si mulier ex qua postumus aut postuma sperabatur, abortum fecerit, nihil impedimento est scriptis haeredibus ad haereditatem adeundan".

75 Scribonius Largus, Conpositiones, ed. G. Helmreich, Lipsiae 1887, 2: "Qui enim nefas existimaverit spem dubiam hominis laedere, quanto scelestius perfecto lam nocere iudicabit".

76 Por. $\operatorname{not}_{\boldsymbol{z}} 69$. 
jej rozwodu, ale rómniez do zajęcia $1 / 6$ jej posagu/propter liberos retentio/.

Plerwszy specjalny reskrypt przeciw winnym przerywania ciaży wydali dopiero panujący razem w latach 198-211 cesarze Septymiusz Sewer /193-211/ i Antoniusz Karakalla/211-217/. Dekret ten wydany ok. $211 \mathrm{r}$. uwazal procuratio abortus za crimen extraordinarium, 1 postanawiał, ze kobieta zamęzna lub tuź po rozwodzie, dopuszczaJąca się podstępnie poronienia wbrew woli męża, winna być przez namiestnika prowincji ukarana czasowym wygnaniem. Podstawą jednak tej sankcji nie było znów dobro 1 życie nie narodzonego dziecka,ale naruszenie godności 1 wadzy ojca oraz jego prawa do potomstwa, które nie pozwalały "pozostawiać bezkarnie kobiety, która pozbawiła swojego męza dzieci". Sam reskrypt nie zachował się w oryginale, ale jedynie $w$ odpisach trzech niemal w tym samym czasie żyjących prawnikóm: Tryfoniusza z 211 roku $^{77}$, Ulpiana z lat 212-217 78 oraz Marcjana z 217 roku 79 . Był to wypadek bez precedensu, ze państwo rzymskie zainteresowało sie po raz pierwszy problemem przerywania ciązy. Rozmyślne sztuczne poronienie przestało juź być rzeczą prywatną, wychodziło z zamkniętego kręgu rodziny i stawało sie faktem ściganym karnie przez państwo jako crimen extraordinarium ${ }^{80}$. Dekret ten musiał być przynajmniej początkowo ściśle przestrzega-

77 Digesta 48.19.39: "Tryphonius libro decimo disputationum: Cicero in oratione pro Cluentio habito scripsit Milesiam quandam mulierem, cum esset in Asia, quod ab heredibus secundis accepta pecunia partum sibi medicamentis ipsa abegisset, rei capitalis esse damnatam. Sed et si qua visceribus suis post divortium, quod praegnans fuit, vim intulerit, ne iam inimico marito filium procrearet, ut temporali exilio coerceatur, ab optimis imperatoribus nostris rescriptum est".

78 D.48.8.8: Ulplanus libro trigensimo tertio ad edictum: Si mulierem visceribus suis vim intulisse, quo partum abigeret, constiterit, eam in exilium praeses provinciae exiget".

79 Digesta 47.11.4: "Marcianus libro primo regularum: Divus Severus et Antoninus rescripserunt eam, quae data opera abegit, a praeside in temporale exilium dandam: indignum enim videri potest impune eam maritum liberis Praudasse".

80 W Digesta Marcjana reskrypt ten przytoczony jest wśród: De extraordinarils criminibus. 
ny, skoro wśród komentarzy $i$ sentencji Pawła odnoszących się do niego spotykamy informacje o innym surowym reskrypcie skierowanym przeciw trucicielom, wytwórcom i dostarczycielom środków aborcyjnych. Stwierdza on, że dostarczyciele środków aborcyjnych i napojów miłosnych winni byé surowo karani ze względu na szerzenie zła: jeżeli winowajca pochodził z nizszych warstw społecznych, winien być skazany na prace w kopalni, jeśli zaś z wyższych, ma być po częściowej konfiskacie majłtku relegowany na odludnaz wyspę. Gdyby zaś na skutek ich działalności zginął mężczyzna lub kobieta, winien byé ukarany śmiercia ${ }^{81}$.

Po niezbyt jednak długim czasie przeciwaborcyjny reskrypt Septimiusza Sewera $i$ Antoniusza Karakalli przeszed Państwo rzymskie więdzyczasie coraz bardziej było przenikane przez zasady religil chrześcijańskiej. Prawo świeckie było jednak do tego stopnia skostniałe, iż mimo że chrześcijaństwo stało się religia państwowa, w jego przepisach nie widać jakichś większych wpływów ewangelicznych. Do końca okresu patrystycznego nie spotkamy juz żadnych świeckich antyaborcyjnych praw państwowych. Co więcej, w 331 r. cesarz Konstantyn Wielki ${ }^{82}$, a w 449 r. Teodozjusz II ${ }^{83}$ redukując powody dające podstawę do rozwodów, pominęli znaną od wieków przyczynę spowodowana sztucznym poronieniem zony invito marito. Przywrócił ja dopiero na jakiś czas cesarz Justynian $533 \mathrm{r}{ }^{84}$ oraz umocnił specjalną nowelą z $536 \mathrm{roku}^{85}$. Po 9 jednak latach /18 XII 542/ Justynian usunął z powrotem procuratio abortus spośród przyczyn da-

81 Digesta $48,19,38,5$ : Paulus 1ibro quinto sententiarum: Qui abortionis aut amatorium poculum dant, etsi dolo non paciant, tamen quia mali exempli res est, humuliores in metallum, honestiores in insulam amissa parte bonorum relegantur. Quod si oo mulier aut homo perierit, summo supplicio adficiuntur".

82 Por. C.Th. 3.16.1.

83 Por. C. 5.17.8.3.

84 C.5.17.11 z dnia 17 XI 533: "Do wyliczonych w konstytucjach win zony /C.5.17.8.3/ dołazczamy następujące: Jeśli zona $z$ wasnej woll dopuści się poronienia, albo jest tak rozwiazzla, że powodowana namiętności ma odwage k quać się wspólnie z męźczyznami, albo té podczas trwającego jeszcze małzeństwa usiłuje pojąć innego małzonka".

85 C.5.17.11.2-3. cp 16,1: "... takie przyczyny przedstawił Toodo- 
jących podstawę do rozwodu ${ }^{86}$. Chrześcijańscy cesarze 1 prawnicy wiedzieli, ze umyślne przerwanie ciąży jest grzechem i przestępstwem, ale nie potrafili tego wyrazić w prawie, które nadal powtarzało wiele skostniałych 1 przestarzałych formuł.

Na zakończenie przeglądu źródeł świeckiego prawa starożytnego odnośnie procuratio abortus, warto sie jeszcze przyjrzeć, jak na ten problem zapatrywało się prawo religijne. otóz zachowało się kilkanaście inskrypcji pochodzących z rozrzuconych po świecie starożytnym świątyń pogańskich, które mówiaz o nieczystości legalnej spowodowanej przerwaniem ciłży, oraz zabraniajaz z tej racji wejścia do sanktuarium przez określonzi ilość dni. Najstarsza z nich pochodząca z Cyreny i datowana na lata 331-326, zwana często "lex catharica" mówi o nieczystości spowodowanej poronieniem płodu: jest ona tym większa im bardziej płód był ukształtowany ${ }^{87}$. Inną inskrypcję spotykamy dwa wieki później welos, gdzie wśród wyliczonych powodów nieczystości, znajdujemy róvnież spędzenie płodu, które zabraniało wejścia do świątyni az przez 40 ani ${ }^{88}$. W tego rodzaju napisach umieszczonych najczęściej przy vejściu do sanktuarium, wyrażała sią̧ przewaźnie wiara ludu, który był przekonany, że zniszczenie płodu jest przestępstwem i zabójstwem, którego zmazanie wymaga pokuty. Ustalona tu po raz piérwszy 40-dniowa pokuta, będzie się odtąd powtarzać często w analogicznych napisach. Można tu jeszcze wspomnieć

zjusz. Przyjmując je od przodków dołączyliśmy trzy inne: jeśli kobieta jest tak zepsuta, ze doprowadziła do spedzenia płodu 1 zasmuciła małzonka pozbawiajzc go nadziei dzieci; jeśli jest tak wyuzdana, że kąpie się wspólnie z mężczyznaini; jeśli podczas trwającego małżeństwa mówi o nowym mężu, to zezwalamy męzowi na posłanie jej aktu rozwodowego i zajęcie posaru".

86 Por. Nowele $117,8 \mathrm{z}$ dnia 18 XII 542.

87 Tekst grecki Nardi 132-134: "Jeśliby jakaś kobieta poroniła, a Jej płód byłby już rozpoznawalny, to ściąga na siebie nieczystość jak po pogrzebie; jeśliby zaś płód nie był jeszcze rozpoznawalny, to ściaga na siebie i swój dom nieczystość jak po porodzie".

88 Napis z Delos, Nardi 192: "Wchodźcie czyści ... po urodzeniu niu dziecka po 7 dniach, po poronieniu zaś po 40 dniach"; por. Napis z Ptolemaidy egipskiej z I w.prz. Chrystusem, Nardi 214: "Ci którzy tu wchodza, winni być czyści według następujacych wskazań ... po przerwaniu ciazzy - po 40 dniach". Napis z Sunion w Attyce II/III w. po Chr., Nardi 394: "po śmierci przez 10 dni, po poronientu przez 40 dni". 
dwie inskrypcje $z$ Lindos na todos 1 ze Smyrny, $z$ poł. II wieku po Chrystusie, które wyznaczają tę samą ilość dni nieczystości legalnej po użyciu środków aborcyjnych, co i po pogrzebie domownika, lub po porzuceniu dziecka ${ }^{89}$. Moźna z tego wnioskować, że procuratio abortus uważane było za zabójstwo.

Ciekawym wreszcie dokumentem dotyczącym naszego zagadnienia jest regulamin prywatnego sanktuarium Dionizosa w Filadeleii w Lidzie, który zobowiazzuje swoich adeptów do nierozprowadzania i niestosowania napojó miłosnych, płynów aborcyjnych i antykoncepcyjnych oraz innych środków używanych do zabijania dzieci, by nie psuć dobrego imienia tej świątyni. Jeżeliby zaś ktoś tego rodzaju przestępstwo popełnił, ma już na zawsze wstęp do niej wzbroniony ${ }^{90}$.

W naszej charakierystyce stosunku czasów przedchrześcijańskich do nienarodzonego dziecka nie może również braknąć, przynajmniej kilku uwag na temat ówczesnej wi e d z y m e d y c z $n$ e $\mathbf{j}$ o życiu embrionalnym człowieka. Wiedza ta bowiem nie tylko zapewniała opiekę nad poczętym życiem 1 ułatwiała jego przyjście na świat, ale równiez /szczególnie medycyna ludowa/ dostarczała wielu wskazań $i$ gotowych recept na wywoływanie sztucznych poronień oraz wskazywała obok antykoncepcyjnych, także wiele konkretnych środków aborcyjnych. Żadne jednak starożytne źródła medỷczne nie informujaz nas o dokonywaniu operacyjnych nieuzasadnionych usuwań żywych pło-

89 Napis z Linaos, Nardi 351: "po środkach aborcyjnych przez 40 dni, po żałobie domowej przez 40 dni"; Napis ze Smyrny, Nardi 351: "Powstrzymajcie sie przez 40 dni po porzuceniu urodzonego dziecka oraz podobną llość dni po przerwaniu ciąży".

90 Napis z Filadelpii, Nardi 193-194: "Pr ktuarium mężczyźni i kobiety, wolni i niewolnicy, niechaj zaprzysiz̨gniz na wszystk1ch bogów ... że nie będa czynić ani doradzać ani téz brać udziału w rozprowadzaniu napojów miłosnych, aborcyjnych $i$ antykoncepoyjnych, lub innych środków do zabijania dzieci, że nie będz szkodzić dobremu imieniu tego sanktuarium. Jeśliby ktoś coś z tych rzeczy ućsynił ... męźczyzna czy kobieta, to niech jui nie wchodzi wi gcej do tego sanktuarium. W nim bowiem przebywaja wielcy bogowie, którzy czuwaja nad tymi rzeczami, i nie ścierpia gwałcicieli swych przykazań". 
dów przez lekarzy: usuwano tylko w ten sposób płody martwe lub takie, które groziły życiu matxi /abortus terapeuticus/, gdyz broniąca etyki lekarskiej przekazymana przez wieki przysięga Hippokratesa zabraniała zabijania zywego płodu. I w tym jednak przypadku proponowano raczej inne środki, które zmuszały organizm kobiety do spontanicznego wydalenia martwego embrionu. Były oczywiście 1 tej dziedzinie duże naduzycia, sugerowane przede wszystkim przez medycynę ludową, która podawała wiele recept aborcyjnych grozacych zdrowiu lub nawet zyciu matki. Opicjalna medycyna starozytna wadragała się zawsze przed niszczeniem żwego płodu. Odwoływano się - niej, szczególnie odnośnie życia płodowego 1 ginekologil, do trzech powszechnie znanych nazwisk: Hippokratesa z Kos /460-370/, Soranosa z Efezu /I w. po Chr./ 1 Galena z Pergamonu /129-199/. Kazdy z nich był zdecydowanym przeciwnikiem nieuzasadrionego przerywania ciąży. W naszych uwagach ograniczymy się przede wszystkim do 1 ch nauk1.

Już samej słynnej przysiędze Hippokratesa widnieje zakaz podawania kobiecie środków aborcyjnych. Czytamy w niej bowiem: "Nie podam nikomu, choćby żądał, smiertelnego leku, ani nie udasele mu rady w tym względzie; nie podam również kobiecte tamponu

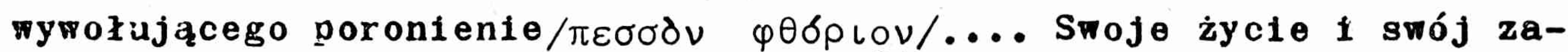
wód zachowam czyste $i$ godne szacunku"91. Latwo zauważy ć że przysiędze na jednym poziomie umieszczone są "śmiertelny lek" oraz nasączony trucizna "tampon aborcyjny", pierwszy zdolny zabié dorosłego człowieka, drugi zaś nie narodzony płód,który implicite uznawany jest za istotę żywa. Widać równieź z powyższego, że odmowa podawania środkóm aborcyjnych należała do podstawowego kanonu zawodowej etyk1 lekarskiej szkoły Hippokratesa. Jego uczniom nie wolno było an1 dokonymać ani wsṕfłdziałać z procuratio abortus, bo to plamiłoby ich źycie i zawód.

o tej przysiędze pamiętało wielu uczniow i zwolenników Hippokratesa. Można tu najpierw wymienié żyjacego w I wieku no Chr.

91 Hippocrates, with an English translation by W.II.S.Jones, vol.1, - Loeb, London 1957, Orkos s.297; Nardi 59-60. 
Skriboniusza Largusa, który informuje, że w oparciu o przysiegę lippokratesa nie wolno żadnemu lekarzowi ani podawać ani wskazywać kobiecie brzemiennej żålnych środków aborcyjnych, by nie zniesławiać medycyny, która jest wiedzaz uzdrawiania, a nie szkodzenia92. Podobrie pisal w II w. słyrny ginekolog Soranos z Efezu podkreślając, że przysį̧ga Hippokratesa zabrania podawania komukolwiek środków aborcyjnych ${ }^{93}$. Analogiczne przekonania spotykamy jeszcze na przełomie IV i v w u Teodora Priscjana, który również głosił, że nie wolno nikomu podawać środków wywołujących poronienie, bo działanie takie plamiłoby nieskalany zawód lekarza ${ }^{94}$. Widać z powyższego, że przeciwdziałanie wszelkim dowolnym poronieniom uważane było w starożytności za elementarny składnik naleźycie rozumianego zawodu lekarskiego. Medycyna bowiem ma działać na korzyść, a nie na szkodę bytu ludzkiego, ma zachowywać i ratować, a nie niszczyć jego źycie.

W swojej ginekologii Hippokrates mówił również wiele o $\varphi \alpha \rho \mu \alpha \varkappa \alpha$ $\varphi \theta 0 \rho l \alpha-$ czyli lekach aborcyjnych, zalecał je cierpiacym kobietom, aby nimi uwolnié ich łona od płodów martwych, gnijących, czy sparaliżowanych. Proponował nawet wprowadzanie bliżej nieokreślonej sondy, gdy łono było stwardniałe, zamknięte i wiadomo było, że wewnątrz płód był juź martwy, by ułatwić jego wydalenie ${ }^{95}$. Wszystko to jednak

92 Scribonil Largi conpositiones, ed. G.Helmreich, Lipsiae 1887, 2-3: Hippocrates, conditor nostrae professionis, initia disciplinae ab iureiurando tradidit, in quo sanctum est, ne praegnanti quidem medicamentum, quo conceptum excutitur, aut detur aut demonstretur a quoquam riledico, longe praeformans animos discentium ad humanitatem. Qui enim nefas existimaverit spem dubiam hominis laedere, quanto scelestius perfecto ian nocere iudicabit? Magni ergo existimavit nomen decusque medicinae conservare pio sanctoque animo quemque secundum istius propositum se gerentern: scientia enim sanandi, non nocendi est medicina".

93. Sorani Gynaeciorum vetus translatio, I, 19,60, ed.V.Rose, Lipsiae 1882, 229: "Niektórzy odrzucają środki aborcyjne powołując się na świadectwo Hippokratesa, który mówi: "Nie dam nikomu środka aborcyjnego przestrzegając tego, co jest właściwe medycynie - zachować i ocalić to, co natura wydała".

94 Theodori Prisciani Euporiston, III Gynaecia 6,23, ed.V. Hose, Lipsiae 1894, 240: "Abortivum dare null1 umquam fas est. Ut enim Hippocratis attestatur oratio, tam duri reatus conscientia medicorum innocens officium non decet macilari. Sed quoniam aut matricis vitio ...".

95 Por. De natura feminarum 37, ed. E.littré /Oeuvres complètes 
były śodki, które dopuszczały poronienie terapeutyczne, mające ratować zdrowie i zycie matki ${ }^{96}$. Wspominał równiéz o dowolnym niszczeniu płodu praktykowanym głównie przez prostytutki ${ }^{97}$, sam jednak wzdragał sie przed tym, uważając płód, wbrew żywym opiniom Empedo-

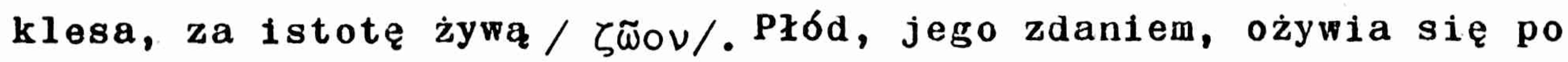
pewnych stadiach rozwoju, o których dokładniej będzie pisał pózniej jego największy uczeń Galen ${ }^{98}$. Stawał się on mianowicie zywym, gdy już miał ukształtowane podstawowe narzady, i ujawniał sie jako taki poprzez ruch. Mimo, lź przed nim zdania filozofów 1 lekarzy były podzielone co do czasu formowania się płodu, on uważał, że piód męski jest juź uformowany ok. 30 dni od poczęcia, a porusza się w' trzecim miesiącu, płód żeński natomiast analog̣icznie ok. 42 dnia 1 czwartym miesiazcu ${ }^{99}$.

Najwięcej jednak szczegółów na interesujący nas temat przekazał nam żyjacy w Rymie za cesarzy Trajana $i$ Hadriana wspominany już słynny ginekolog Soranos z Efezu. Odróźniał on jasno środki antykoncepcyjne $/ \alpha \tau \delta \varkappa \iota \alpha /$, które przeszkadzaja poczęciu, od środków aborcyjnych $/ \varphi \theta 0 \rho l \alpha /$, które niszczą to, co zostało poczęte. Informuje nas ponadto o różnych opiniach panujących w II w. na temat godziwości uźywania środków aborcyjnych. Przedstawiciele szkoły Hippokra-

d'Hippocrate, traduction nouvelle avec texte grec/, VII, Paris 1851, 380-381; Gynaecologia ITI: De sterilitate feminarum, ed. Littré, VIII, 452; por. Nardi 74-76.

96 Obszerniej na temat proponowanych przez Hippokratesa aborcyjnych środków terapeutycznych, por. Nardi 72-82.

97 Por. De carnibus 19, Littré VIII, 610, Nardi 79: "Publiczne hetery chodząc z mężczyznañ wiedzą kiedy zachodza w ciąże. Niszczą sob1e płód wewnįtrz, a gdy już jest umarły, sam wypada jak ciało".

98 Por. note 109.

99 De natura infantis 18, Littré VII, 498, Nardi 108: "I stało się juz dziecko. Zachodzi to dla płodu żeńskiego najdalej $w 42$ dniu, dla męsiego zaś najdalej w 30 dniu. W tym czasie następuje to z reguły, ale rnoźe być również nieco woześniej lub później ... Wydzielenie się członków ma niejsce w przypadku płodu żeńskiego najdalej w ciłgu 42 dni, w przypadku zaś żeńskiego w ciagu 30 dni". O dalszych szczegółach życia embrionalnego w ujęciu llippokratesa por. Nardi 98-116. 
tesa, zgodnie ze złożona przysiega, odrzucali zdecydowanie przede wszystkim środki medyczne, inni znów dopuszczali je, ale tylko w określonych przypadkach - w celach terapeutycznych, aby ocalić zdrowie i źycie matki, a nie po to, by ukryć cudzołóstro lub zachować urodę; inni wreszcie mówili tylko o środkach antykoncepcyjnych, bo uważali, że bezpieczniej jest przeszkodzić poczęciu, niz przerwać ciąźę ${ }^{100}$. Sam równiez za tymi ostatnimi się opowiadał. Z "Ginekologii" Soranosa wynika, ze wego czasach procuratio abortus było nierzadko stosowane 1 zalecane nawet w podrecznikach lekarskich, choć trudno rozstrzygnąć, czy zalecenia te odnoszą się do owych ściśle określonych przypadków, czy też do nagminnego stosowania. Rozróżnia też różne typy poronienia. Mówi o Ěnpola.

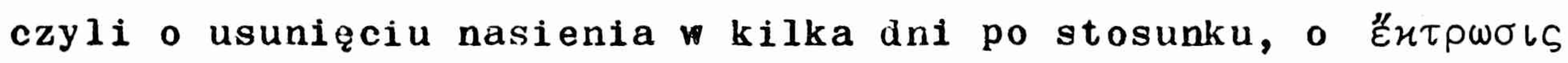
czyl1 o zniszczeniu embrionu w drugim lub trzecim miesiącu, czy wreszcie o $\omega \mu \circ \tau o \varkappa l \alpha$ czyli przedwczesnym porodzie, kiedy płód jest już ukształtowany, $i$ choć słaby, to jednak zdolny do życia ${ }^{101}$. Pisze również o objawach zbliżającego się poronienia ${ }^{102}$, a nawet

100 Sorani Gynaeciorum vetus translatio latina a Dietzio edita, ed. I, 19,60, ed. V.llose, Lipsiae 1882; 229-230; D81ger 26,Nardi 336-338: "Atokion" i "Pthorion" nie oznaczają tego samego: pierwsze zapobiega poczęciu, drugie zaś niszczy płód. Także "ekbolion" niektórzy uważaja za synonim "fthorion", choć inni odróżniają zaznaczając, że nie chodzi tu o medykamenta, ale o mechaniczne wstrząsy i skoki. W tym sensie właśnie Hippokrates odrzucając medyczne środki wywołujace poronienie w ksizzzce "O naturze dziecka", używał terminu "ekbolion". I w tej dziedzinie sa różne zdania. Jedni odrzucajłz środki wywołujące poronienie/fthoria/, ponieważ powołuja sie na słowa Hippokratesa: "nie podam níkomu środka wywołującego poronienie, ponieważ do istoty sztuki lekarskiej należy strzec i bronić tego, co natura zrodziła". Inni przecirnie, zalecają je, ale tylko w określonych wypadkach, a więc nie wtedy, gdy brzemienna po cudzołóstwie żąa ingorencji lub, by przez poród nie stracić swej urody, ale tylío wtedy, żeby zaćgegnać niebezpieczeństwo, które by prawdopouobnie wystąpiło przy naturalnym porodzie, tzn. gdy łono jest za małe i niezdolne do donoszenia płodu, alio gdy przy szyjce macicznej znajduja się guzy i pęknięcia, lub wobec innego uzasadnienia. Inni znów mówią o środkach antykoncepcyjnych /atokia/i my zgadzamy się z nimi. Bezpieczniejsze jest bowiem przeszkodzenie poczęciu, niż spędzenie jłodu".

101 Tamże, II, $13,47, \mathrm{~s} .344$.

102 Tamże, I, $18,59, \mathrm{~s} .228-229$. 
proponuje konkretne środki i zalecenia aborcyjne, dostosowane do różnych okresów płodu. Przytoczymy wocie dłuższy jego fragment na ten temat, który nam uświadomi, jakimi środkami w II w. przerywano ciązę ${ }^{103}$. Wiele z nich będzie później piętnowane przez 0jców Kościoła.

103 Tamże, I, 19,64-65, s.232-234, Nard1 339-343: "Po zajściu w c1.żż trzeba najpierw do 30 dnda czynić wszystko przeciwnie, niz zalecaliśmy przy pielęgnowantu ciazży. W celu pozbycia się poczęcia, nalezy się szybciej poruszać, wiele chodzić, trzaść się gwałtownie na pojazdach, gwałtownie skakać, dźwigać cięzary ponad swoje siły, brać wywary moczopędne zdolne również wywołać miesiaczkę, opróżniać i czyścić łono ostrymi płynami, wstrzykiwać sobie ciepły i delikatny olej albo namaszczać nim lub mocno nacierać okolice łonowa, podbrzusze i lędźwia, kąpać się każdego dnia w słodkiej niezbyt gorącej wodzie, przedłużać kąpiel, pić kwaśne wino i jadać ostre pokarmy. Jeśli to nie pomaga, to robić sobie nasiadówki na wywarze z nasienia lnu, $z$ bożej trawy, malwy, dzikiego ślazu i bylicy oraz stosować okłady z tych samych składników lub wstrzykiwanie starego oleju samego lub zmieszanego ze sokiem ruty, niekiedy z miodem lub sokiem irydy, albo piołunem zmieszanyin $z$ miodem lub guma, albo z orkiszem z mioaen, albo balsamem syryjskim. Jeśli poronienie nadal się opóźnia, to nie stosować już więcej zwyczajnych okładów, ale używać okładów z maku łubinu z źółcía byka i piołunem lub plastrów z tych rzeczy ... Kobieta zamierzajaca spędzić płód winna dwa lub trzy dni wcześniej poddawać się długim kąpielom, mało jeść, stosomać zmiękczające tampony, powstrzymywać się od wina, a następnie pozwolić sobie otworzyć żyły i upuścić trochę krwi. Prawda jest bowiem to, co już "Aforyzmach" Hippokratesa powiedziano nie o chorej, ale o zdrowej, że kobieta skaleczona w cizży, spędza płód. W ten sam sposób jak pot, mocz lub kał po pobudzeniu pewnych tkanek opuszczaja swoje miejsce, tak również $i$ to, co zostało poczęte / ${ }^{\circ} \sigma u \lambda \lambda \eta \theta \varepsilon \nu /$, wypada po uprzednim rozszerzeniu się łona. Po upuszczeniu krwi wskazane jest również mocno się wstrząsnąć na powozie. Teraz na osłabionym juź siedzeniu taki wstrząs jest już bardziej skuteczny. Trzeba nadto używá́ zmiękczających suppozytoriów/pođapasek/. Jeśliby któraś z powodu upuszczonej krwi miała sięźle poczuć i być osłabiona, to niech siz̨ najpierw osłabi przez nasiadówki, kąpiele i zmiękczające suppozytoria, pijqc przy tym wodę, mało jedząc, stosując środki przeczyszczające i dodając do kąpieli środki zmł ękczające. Potem zaś niech załozy sobie tampon aborcyjny. Używać zaś do niego składników niezbyt mocnych, aby nie wywołać zbytnich zakłóceń ubocznych i goraczki. Do najłagodniejszych zaliczane sa składniki z mirtu, nasienia lewkonii i gorzkiego łubinu, które należy uformować $z$ wodą w tabletki wielkości nasienia bobu; albo też 3 drachmy liści ruty, 2 drachmy mirtu lub lauru zmieszanych z winew. Inny pewniejszy tampon to: części lewkonii i boskiej rzeżuchy, piołunu i mirry zmieszane jo lówno z wodiz. Kobieta chcąca tego używać winna najpierw wziąć kąpiel lub osłabić się 
Niemal wszystkie środki zalecane przez Soranosa sa różnego rodzaju trującymi płynami i lekami, które po zastosowaniu młały zmusić organizm do spontanicznego wydalenia martwego płodu. Niechętnie mówił o usuwaniu ci zży metodą chirurgiczną, a wiemy, że tego rodzaju operacje terapeutyczne przeprowadzali w starożytności najwybitniejsi lekarze, jak: wspominany już Hippokrates, Asklepiades z Prusy, Erasistratos z Keos /IV w.prz.Chr./, Herofil z Chalcedonu /IV w.prz.Chr./ $i$ on sam. O narzędziach używanych do tego celu informuje Tertulian ${ }^{104}$. Było to jednak poronienie terapeutyczne, które jak zobaczyny, dopuszczali nawet niektórzy autorzy chrześcijaíscy, jak Tertulian $i$ św. Augustyn ${ }^{105}$. o jego stosowaniu informuje nas jeszcze ok. $400 \mathrm{r}$. wspominany już słynny lekarz afrykański Teodor Priscjan, w swym dziele "O chorobach kobiecych"106.

nasiadówkami, a jeśli to przez dłuższy czas nie pomaga, ponownie stosować nasiadówki i używać wspomnianego leku. Wiele jeszcze innych rzeczy niektórzy zalecają, ale trzeba się wystrzegać środków zbyt gwałtownie działających i niszczenia embrionu przez jakieś ostre narzędzie. Istnieje bowiem niebezpieczeństwo zranienia któregoś z sąsiednich narządów. Po spędzeniu zaś płodu, należy się leczyć jak po zapaleniu".

104 Por. Tertullianus, De anima 25,5, CCL 2, 820, ALP I, 240: "Wśród narzędzi lekarskich znajduje sie nie tylko instrument do otwierania siłą, przy pomocy ruchu obrotowego, części rodnych, nie tylko okrazgły nóż do ostrożnego poodcinania wich wnętrzu członków, nie tylko tępy hak do dokonywania gwałtownego porodu i wyciągnięcia nlebezpiecznego płodu, do popełniania na ślepo morderstwa rabunkowego; zwie się ów lancet embriosfastes, jako ze nim zabija się żywe dziecię. Posługiwali się tymi narzędziami Asklepiades, Erasistratos, Herofil, i nawet znany z łagodności Soranus, a wszyscy byli przeświadczeni, że poczęty płód żye".

105 Por. Tertullianus, De anima 25, 4-6, CCL 2,820, ALP I, 240; Augustinus, Enchiridion 23,86, PL 40,272.

106 Euporiston III, 6,23, ed.V.Rose, Leipzig 1824, s.240, Nardi 538-544: "Nie wolno nigdy nikomu podawać środka aborcyjnego. Jak bowien świadczy nauka Hippokratesa, nie wypada plamić nieskalanego zawodu lekarza śriadomościa tak. wielkiej winy. Ponieważ jednak kobiety bywaja narażone na niebezpieczeństwo na skutek defektów łona, albo niemoźności wieku/matricis vitio aut aetatis impossibliitate/, dopuszcza się z tej racji nierzadko poród przyśpieszony. Brzemiennym bowiem narażonym na niebezpieczeństwo utraty życia trzeba zapewnić ocalenie często przez stratę jeanego płodu /expedit praegnantibus in vitae discrimine constitutis sub unius partus saepe iactura salutem mercari certissimam/, podobnie jak dla drzew zbawienne jest obcinanie narosłych gałezi, a dla obcizżonych 1 miotanych.podczas burzy okrętów ratunkiem 
Zalecenia Soranosa długo zyły w świadomości starożytnych. Świadczą o tym wielokrotne przekłady i przeróbki jego "Ginekologi1", jak np. łaciński północno-afrykański przekład Muscjusza z VI w. ${ }^{107}$, czy teź pochodząca z tego samego czasu przeróbka tego dzieła dokonana przez Aecjusza ${ }^{108}$. Soranos długo pozostawał podstawowym źródłem informacji nie tylko dla lekarzy, ale i dla kobiet dopuszczajz̨cych sie samodzielnego spędzania płodu.

Wiole Informacji na poruszany przez nas temat dostarczy nam równiez jeden z najwierniejszych przedstawicieli tradycji Hippokratesa, słynny Galen z Pergamonu, przyboczny lekarz cesarski Marka Aureliusza, Lucjusza Werusa i Kommodusa. W rozwoju płodu rozróżniat on cztery okresy: your-do 6 dnia od poczecia, kiedy zarodek jest jeszcze nasieniem; $\chi{ }^{\prime} \eta \mu \alpha$ - produkt poczęcia, które staje się powoli ciałen; ž $\mu \beta p v o v$ - płód, który rozwija się w członki jak drzewo w gałęzie; $\pi \alpha \iota \delta l o \nu$ - dziecié, które już się porusza i jest

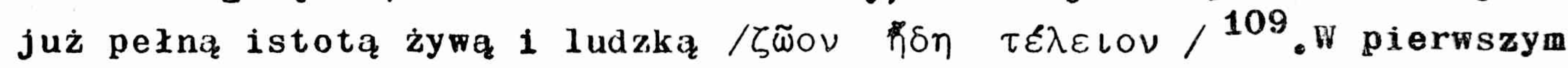
okresie, do 7 dnia po stosunku nie można jeszcze, jego zdaniem, mó-

jest wyrzucenie /ładunicu/".

107 Sorani gynaeciorum vetus translatio latina, ed.V.Rose, Leipzig 1882.

108 Tetrabiblos contractae ex veteribus medicinae.

109 De semine 1,9, ed.Kuhn, Bd.IV, Lipsiae 1822, 542-543, Nardi 95: "Cały rozrój płodu dzielimy na cztery okresy: Pierwszym jest ten, w któryin, jak o tym świadcza poronienia i sekcje, dominuje wyglizd nasienia. Do niego nawet godny podziwu Hippokrates nie odnosiz nazwy "kyema", ale go nazywał produktem poczecia 6 dni. Drugi okres ma miejsce wtedy, kiedy zarodek napeznia się krwiz̨, pojawia sie serce, mózg i żołızdek, i choć są jeszcze nieokreślone $i$ bezkształtne, to jednak majaz juz pewnaz trwałość 1 znaczną wielkość. Substancja tego płodu jest teraz podobna do ciała, a nie do nasienia. Dlatego tez nie spotkasz n1gdzie, żeby Hippokrates nazywał to "gone", ale je nazywa, jak juź powiedziałem "kyema". W trzecim okresie już jasno moźna dostrzec trzy wspomniane principia oraz zarys kształtu i jakby cjeń wszystkich innych cz̨óci. Widać już wyraźnie konfiguracje trzech wspomnianych principiów,bardziej juz wydzieloną część odpowiadająca brzuchowi oraz lepiej zaznaczone części odpowiadające przyszłym członkon. Te nastęnie, jakby powiedział Hippokrates, pazczkjł na podobieństwo gałęzi. I ostatni okres, kiedy już wszystkie członki się ukształtowały, a grodny podziwu Hippokrates nie nazywa już tego "emkrionea", ale dzieckiam "paidion". Zaczyna się już ono poruszać i podskakiwać, jak istota żywa". 
wic o poczeciu, a wonsekwencji i o poronieniu. W zwiazzku z tym zalecat on, jak sam relacjonuje, pewnej brzemiennej tancerce podskakimać wysoko aź do pośladków welu pozbycia się nasienia, skutkiem czego wypłynął z niej rodzący się 6-dniowy zarodek, który później dokładnie opisuje ${ }^{110}$. Rada ta nie była jego zdaniem złamaniem przysiegi Hippokratesa, poniewaz nie dotyczyła płodu i nie

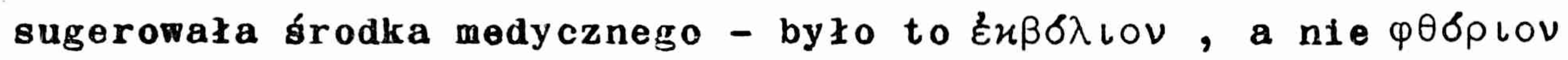
o jaki wiej chodziło. Zdarzało się jednak, że i Galen proponował pewne konkretne recepty aborcyjne, z których jednak trudno odczytać, czy chodziło nich o usunięcie płodów martwych, czy też żywych, ale z pominięciem przysiegi swego Mistrza ${ }^{11}$. Był to bowiem jeden ze sposobów omijania litery prawa przysiegi hipokratejskiej, stosowany często przez lekarzy. Takie zalecenia, jak: skoki, wstrząsy, dźwiganie cięzarów, nacierania, nasiadówki, spoźywanie ostrych pokarmów i napojów, czy upuszczanie krwi, nie uwłaczały przysiedze, poniewaź nie były medycznym środkiem aborcyjnym.

Obok powyższych wskazań krążyło wśród starożytnego społeczeństwa wiele innych zaleceń, sugerowanych nie tylko przez medycynę ludową, ale róvniez przez botaników, fllozofów, położne, czy lekarzy nadwornych. Tak np. aborcyjne waściwości niektórych roślin wskazywał swojej "Botanice" słynny Teoprast $/ 372-287 / 112$ oraz

110 Medicorum graecorum opera, quae exstant, IV, De foetum format1one, ed. C.Gottlob Kuhn, Lipsiae 1822, 652, Nardi 68-69: "Widziałem owoc pocz ̨zcia, który będąc 6 dni w łonie, wypadł na zewnztrz ... Poradziłem jej/tancerce/ podskakiwać aź do pośladków, a kiedy juz 7 razy podskoczyła, produkt joczęcia wypadı na ziemię".

111 Por. Galenus, De antidotis VII 6/5, Nardi 281: np. "antidotum zq:ane Indyjskim Orbano, aby usunzé płód z łona; antidotum Eliusza Galla, na które zgadzał się Cezar i używał Karmes ... usuwa płody bezboleśnie; antidotum hitrydatesa Eupatora ... usuwa także płody hartwe i głęboko zakorzenione".

112 Por. Botanica IX 18, 8: "Paproć kobieca - jeśliby była dana kobiecie brzemiennej, mówiz, że poroni, a jeśliby ta nie byla brzemienna, spoworluje, że stanie siz̨ bezpłodną"; IX 18,11: "Ponadto w Achai, a szczególnie w Cerynii, jest pewien typ winorośli, której wino powoduje poronienia u kobiet". 
Pseudo-Apulejusz z Madaury ${ }^{113}$, wiele aborcyjnych Informacji z medycyny ludowej połaczonej niekiedy z magia przekazal nam wojej "Historii naturalnej" Pliniusz114, pewne recepty aborcyjne proponował równiej przyboczny lekarz Juliana Apostaty Oribasius 115 Marceli. Empiryk ${ }^{116}$. Wszystkie te Informacje dawały w sumie cała game różnego rodzaju środków, wskazań 1 zaleceń poronieniowych, które poza nurtem oficjalnej medycyny, przekazywane były ustnie, szczególnie w świecie kobiecym i prywatnie praktykowane.

Jak wreszcie do problemu sztucznego przerywania ciazzy ustosunkowywała sie B 1 b 1 i a, która przeciez, jak wiemy, wywierała decydujący wpływ na postawy życiowe 1 moralnośc starożytnych chrześcijan? otóz mimo tego, iż jak widzieliśmy, sztuczne poronienia były od wieków niekiedy nawet nagminnie praktykowane, a życie ludzkie było dla Izraelitów w najwyżzzej cenio/Jb 2,$4 ; 7,1 /$, to Biblia na ten temat milczy zupeznie i nie piętnuje tego przestępstwa ${ }^{117}$. Raz tylko ksieggi Starego Testamentu wspominaja o przypadkowym poronieniu spowodowanym podczas bójki dwóch mężczyzn ${ }^{118}$. W brzmieniu tego

113 Notitiae de herbarum virtutibus 114, Nardi 536: "Ad aborsum. Herbae cucumenis sylvatici radices ad tertias in aqua coquantur, et inde se sublavet".

114 Naturalis historia $X 63 / 83 /, 172$ : "... in hominum genere maribus deverticula veneris excogitata ... Peminis vero abortus. Quantum in hac parte multo nocentiores quam fere sumus": XXV $3 / 7 /, 25:$ "sed quae fuit venia monstrandi qua mentes soiverentur, partus eliderentur, multaque similia? Ego nec abortiva dico ac ne amatoria quidem, memor luculium imperatorem clarissimum amatorio perisse, nec alia magica portenta, nisi ubi cavenda sunt aut coarguenda, in primis fide eorum damnata. Satis operae fuerit abundeque praestatum vitae salutares dixisse, ac pro ea inventas"; VII 6/5/, 41: "... melior color marem ferenti et faciliór partus, motus in utero quadragesimo die. Contraria omnia in altero sexu, ingestabilo onus, crurum et inguinis 10vis tumor, primus autem XC die motus".

115 Curationum liber. Ad menstrua provocanda, in: Oribasil Sardi Juliani Archiatri Euporiston, 1ib.III, Nardi 507.

116 De medicamentis 30,19, ed. G.Helmreich, Lipsiae 1889, 3.318: "abigit etiam conceptum feminis praegnantibus datum".

117 Por. J.Lach, Milczenie Biblil wokóz problemu usuwania płodu z łona matki, CT 52/1982/ z .3, 57-65.

118 Wj 21, 22-23: "Gdyby mężczyźni bijac sie uderzyli kobiete brzemienną powodujazc poronienie, ale bez jakiejkolwiek szkody, to /winny/ zostanie ukarany grzywną, jaką/na nich/ nałoży mąz tej 
tekstu łatwo zauważy wpływy praw wschodnich, szczególnie Kodeksu Hammurabiego ${ }^{119}$, odnośnie sankcji za równie przypadkowe spowodowanie poronienia. Tam i tu na pierwszym planie wyeksponowane jest życie 1 zdrowie matki, a dopiero później życie nie narodzonego dziecka, które uwazane jest za rzecz i wasność męza tej kobiety. Nie ma tu mowy o jakimkolwiek zabójstwie, ale o wyrządzeniu krzywdy męzom1, który sam ustala wysokość odszkodowania za poniesioną strate. Tak samo rozumial ten tekst $i$ przełozy z hebrajskiego na lacine 6́.Hieronim $\mathbf{s w o j e j ~ W u l g a c i e}{ }^{120}$.

W III w. przed Chrystusem 72 hebrajskich tłumaczy przełozyło Aleksandril na jezyk grecki cały Stary Testament/Septuaginta/. Pod wpływem współczesnych soble pogląd6w na życie embrionalne człowieka, tłumacze przełożyli interesujace nas miejsce nieco inaczej: rozró źnili miegdzy poronieniem płodu ukształtowanego i poronieniem płodu nieukształtowanego. Ze względu na duże znaczenie tego przekładu dla naszych późniejszych rozwaźań, przytoczymy je tu w całośc1 :

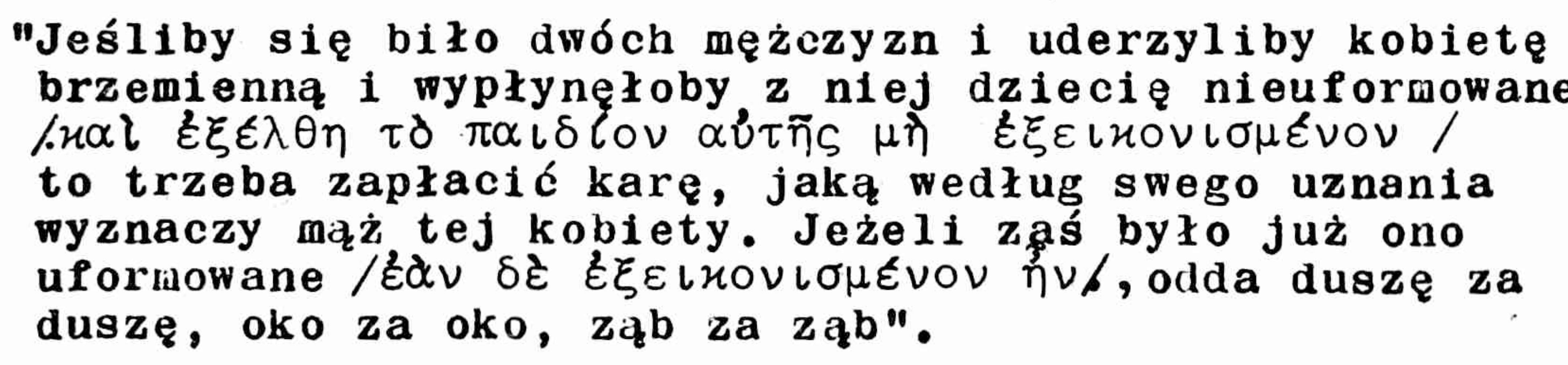

Widać z powyższego, że płód uformowany, to byt ludzki oźywiony

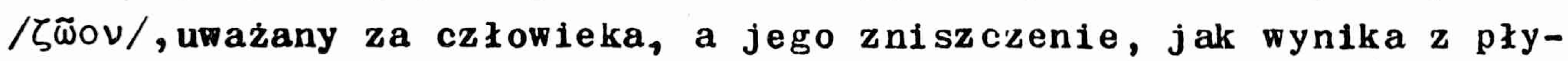
nacych z tego konsekwencji /duszę za duszę/ jest zabójstwem. Zniszczenie natomiast płodu nieuformowanego, jest jedynie krzywda wy-

kobiety, i wypłaci ją za pośrednictwem sędziów polubownych. Jeżeli zaś poniesie jakąś szkodę, wówczas odda życie za życie, oko za oko, ząb za ząb".

119 Por. noty 48-49.

120 Vulgata, Exodus 21, 22-23: "Si rixati fuerint viri, et percusserit quis mulierem praegnantem, et abortivum quid fecerit, sed ipsa vixerit; subiacebit damno quantum maritus mulieris expetierit, sed arbitri iudicaverint. Sin autem mors eius fuerit subsecuta, reddet animam pro anima". 
rządzona mężowi kobiety, który, wyznacza wysokość kary za jego unicestwienie. W zdaniach tych przejawia sie nie tylko stara fizjologia o embrionalnym rozwoju człowieka, ale równiez ocena nie narodzonego dziecka, dostosowana do stadiów jego rozwoju. Widać tu takze sprzec1w wobec żywch w tyı czasie if Aleksandrii założeń stoickich, uważających płód za część matki, a zarazem nawizzanie do nauki Hippokratesa, Arystotelesa i ludowych przekonań wyrażonych w kultowym lex catharsis z Cyreny. Jest to równieź pierwszy tekst prawny potępiajacy poronienie jako zabójstwo/homicidium/, jaki pojawił się w hellenistycznym aleksandryjskim środowisku żydowskim. W tym samym duchu przełoży go na język łaciński W II w. po Chrystusie anonimowy tłunacz i twórca Vetus Latina ${ }^{121}$.

Znaczenie przekładu Septuaginty jest w naszych rozważaniach tym większe, że przez kilka następnych wieków był on oficjalnym komentowanym tekstem nie tylko dla Żydów, ale i ala 0jców Kościoła aż do czasu powstania Wulgaty /384-389/, choć 1 później często się nim posługiwano. To waśnie tłumaczenie formowało stosunek starożytnych chrześcijan do problemu przerywania ciazży. I oni w większości rozróżniali płód nieuformowany i uformowany, 1 tylko zniszczenie tego ostatniego uważali za zabójstwo. Tak go również rozumieli najwybitniejsi przedstawiciele patrystyki wschodniej $i$ zachodniej, jak np.: Tertulian, Orygenes, Rufin, Lucyfer z Cagliari, Efrem Syryjczyk, Konstytucje Apostolskie, Hieronim, Augustyn, Cyryl Aleksandryjski, Teodoret, Maksym Wyznawca i inni. Ich interpretacje omówimy szczegółowo w drugiej części naszego artykułu.

Pod wpływem Septuaginty zmieniły sie równiez zapatrywania Żydów na rozwój embrionalny człowieka. Tak np. Filon Aleksandryjski /20 prz.Chr. - 50 p.Chr./ uważał płód uformowany za człowieka ukrytego czasowo w łonie, niby w laboratorium natury, tak jak po-

121 Por. Augustinus, Quaestiones in heptateuchum. Quaestiones Exod1 80, CCL 33,110-111: "Si autem 1itigabunt duo viri et percusserit mulierem in utero habentem, et exierit infans eius nondum formatus: detrimentum patietur quantum indixerit vir mulieris et dabit cum postulatione. Si autem formatum fuerit, dabit animam pro anima". 
Sagg w pracowni rzeźbiarza. Zniszczenie takiego płodu jes.t oczywiście zabójstwem, bo unicestwia jeden z najpiękniejszych tworów natury - człowi eka ${ }^{122}$. Płód ten, szczególnie męski, formuje się, jego zdantem, w ciagu pierwszych 40 dni od poczęcia ${ }^{123}$. Trudno mu się jednak było pogodzić z rozpowszechnionymi poglądami stoickimi, ze płód, niezaleznie od fazy swego rozwoju, jest częścia matki. Wykazuje więc, że jest to niemożliwe, bo płody urodzone nawet przedwcześnie, potrafia samodzielnie żyé, bez pomocy organizmu matki. W związku z tym każdy, kto niszczy płód uformowany, jest mordercą

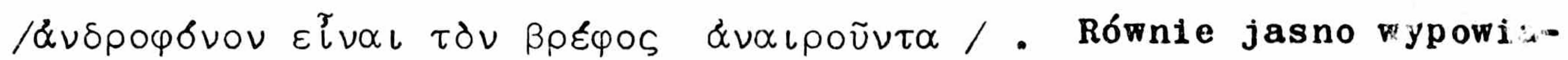
dał sie na ten temat inny przedstawiciel judaizmu hellenisty czrego Józep Flawiusz /37-96/. Chociaż $w$ interpretacji interesującego nas

122. De spec1alibus legibus 108-109, ed.F.H.Colson,Loeb VII,545-546: "Jeśli ktoś podczas bójki zadałby cios brzemiennej kobiecie p brzuch, a ona poroniła, to gdy wyrzucony płód okazał sie nieukształtowany i nieuformowany, niech zostanie ukarany za gwałt i za to, że przeszkodził płodnej i twórczej naturze urodzić jedną z najpiękniejszych istot - człowieka; jeśli natomiast płód okazał sie już uformowany, a jego członki przybrały już swoje funkcje i właściwości, niech będzie zabity.

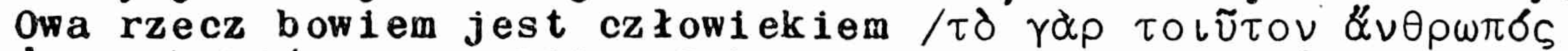

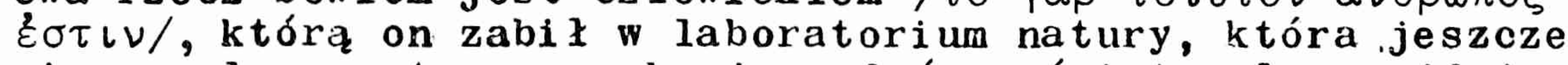
nie uznała za stosowne, by ją wydać na świat, ale znajduje się w nim jak statua w pracowni rzé́biarza, i nikt nie może żądać, by była stamtąd usunięta i porzucona".

123 De vita Mosis 2,84: "... okres pierwszych 40 dni jest najbardziej twórczy, a mówi się o nim, że człowiek jest w nim formowany jak w laboratorium natury"; In Genesim 4,154, Philo, Supplement I, Questions and answers on Genesis, ed.R.Miarcus, Loeb, London 1961, 438: "Hodzenie bytów żywych dokonuje się w pierwszych 40 dniach, podczas których, jak lekarze mówią, nasienie wlane do łona jest formowane, i staje sie bytem ukształtowanym, szczególnie gdy chodzi o płód męski".

124 De specialibus legibus 117-118, ed.F.H.Colson, Loeb VII, London 1958, ss.548 i 550: "Mów1 się, że płody znajdujące się jeszcze w łonie brzemiennej sa jej częścia ... Rodząc się jednak przerywaja ową symbiozę, pozostawione sobie saz żye, 1 nie brakuje im zadnego z tych elementów, które integrują ludzką nature. W zwiazku z tym, morderca bez watpienia jest ten, kto niszczy płód. Prawo bowi em nie dotyczy wieku, ale naruszania rodzaju /1udzkiego/"; por. De virtutibus 138 . 
tekstu $N j$ 21, 22-23/ trzymał się raczej pierwotnej myśli hebrajskiej ${ }^{125}$, to jednak zniszczenie płodu uważał za zabójstwo, a kobietę, która się go dopuściła, nazywał wprost morderczynią dziecka

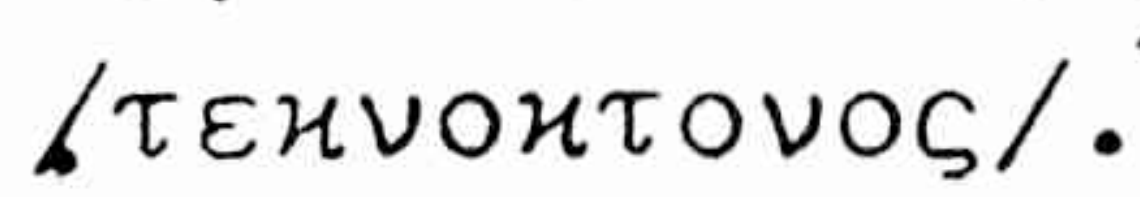

W podsumowaniu naszych rozważań, które miały za zadanie ukazać stosunek czasów przedchrześcijańskich do poczętego, ale nie narodzonego jeszcze życia ludzkiego, oraz przybliżyć tło 1 okoliczności, w których przyszło działać pierwszym chrześcijanom, trzeba stwierdzić, ze w okresie tym praktykowano często, i większości wypadków bezkarnie, przerywanie ciąży. Płód ludzki, szczególnie nieuformowany, traktowano przeważnie na równi z rzeczami materialnymi. Pierwsze konkretne świadectwa o istnieniu sztucznego nie uzasadnionego poronienia spotykamy w Grecji od V, a w Rzymie od III wieku przed Chrystusem. Szczególnie często było ono praktykowane na przełomie naszej ery, w I wieku przed, $i$ I wieku po Chrystusie. Wśród przyczyn prowadzzeych do tego rodzaju czynów widzimy najczęściej: ukrycie i zniszczenie owocu cudzołóstwa, prostytucja, pragnienie zachowania urody ciała, chęć ograniczenia potomstwa, niechęć do małżonka i ojca poczętego dziecka, gwałt oraz względy Pinansowe /tancerki, aktorki/. Przerywano też ciążę ze względów terapeutycznych. Sztucznego poronienia dokonywały sobie przeważnie same kobiety, wspomagane niekiedy przez niańki, połoźne 1 przyjaciółki. Wskazówek $i$ gotowych recept do $i \mathrm{ch}$ przeprowadzania dostarczała przewaźnie medycyna ludowa. Jedynie poronienia terapeutyczne przeprowadzane były z pomoca lub wiedzą zawodowych lekarzy i połoźnych. Sztucznych poronień dokonywano najczęściej przy pomocy różnorodnych trujących płynów/potiones ad aborsum, pocula abortionis/. aborcyjnych tamponów i pessariów, jak również gwałtownych skoków, biegów, wstrząsów, ostrych pokarmów i kąpieli. Wszystkie te środki miały zmusić organizm kobiety do spontanicznego wyrzucenia płodu.

125 Antiquitates IV 8,33, tłum. E.Dąbrowski /Dawne dzieje Izraela, Poznań 1979/, 249-250: "Jeśli ktoś kopnie kobietę brzemienną, a ona skutkiem tego poroni, zostanie przez sędziów skazany na karę pieniężna za to, że przez zniszczenie płodu, zmniejszył liczbę ludności: zapłaci równiez odrębnie mężowi tej niewiasty. Gdyby zaś ona umarła od ciosu, winowajca także umrze, jako że prawo domaga się zadoścuczynienia życiem za życie".

126 Contra Appionem 2,254: "/Prawo/ nakazało wychowywać wszystkie 
Chirurgiczne usuwanie ci żży odbywało się tylko ze względów terapeutycznych. Źródła odnotowuja wiele wypadków śmiertelnych lub powikłań zdrowotnych wywoływanych przez działalność aborcyjną. Jeśli chodzi o sankcje karne za nieuzasadnione przerwanie cląży, to pojawiły sie one najwcześniej w prawodawstwie wschodnim/babilońskim, asyryjskim, hetyckim $i$ żydowskim/, ich ślady spotykamy później od V wieku przed Chrystusem w Grecji, a konkretne reskrypty przeciwaborcyjne dopiero na poczatku III wieku w Rzymie. Zasadniczym powodem tego opóźnienia $i$ niezdecydowania na Zachodzie były głęboko zakorzenione 1 oddziałujące mocno na życie społeczeństwa poglądy stoickie, które nie uważały płodu za istotę żywa, ale za pars viscerum matris. Przeciw tym poglądom zapoczątkowanym jeszcze przez Empedoklesa /490-430 prz.Chr./ występowała medycyna ze słynną przysięą Hippokratesa, częściowo filozofia, a od III wieku przed Chrystusem także judaizm idący za myślą i prawem Septuaginty. Takiemu oto światu, niechętnemu d la nte narodzonego życia,miało stawié czoło chrześcijaństivo głoszące zasadę, ze każde nieuzasadnione zniszczenie poczętego życia jest morderstwem.

Ciąg dalszy w następnym zeszycie.

Ks. Stanisław Longosz - Lublin

DIE KIRCHENVÄTER UND FRUCHTABTREIBUNG /Zusammenfassung/

Das 1st der erste Teil des Artikels, der die Abtreibung in der vorchristlichen Zeit behandelt. Er bildet einen umfangreichen Hintergrund, auf dem der Autor das Verhaltnis der Altchristen zur Abtreibung darzustelien beabsichtigt. Die vorchristilche Zeit ist anhand der literarischen, philosophischen, rechtswissenschaftliche, medizinischen und biblischen Quelien charakterisiert. Aus den literarischen Quellen fuhrt der Autor die Zitate zum Thema der Abtreibung aus der wedischen, zoroastrianischen, altagyptischen, griechischen/Aischy10s, Euripides, Plato/ und romischen Literatur/Cicero, ovidius, Iuvenalis, Plinifs, Apuleius, Seneca/ an. Aus philosophischen quellen zittiert er die AuBerungen des plato, Aristotelos und der Stoiker.

dzieci l obwieszczało kobietom, by nie przerywały ciaży 1 innymi środkami. nie niszczyły poczętego płodu. [Kobieta) okazuje sie w tym wypadku morderczynia dziecka, bo niszczy dusze i pomiejsza rodzaj [ludzki]". 
Aus jurlstischen Quellen gibt or an: das Gesetzbuch von Hammurabi, das altassyrische, hethitische und agyptische Gesetz, aus dem griechischen Recht die Sentenzen von Licurg und Solon, aus dem romischen Gesetz das Reskript der Kalser Septimius Severus und Antonius Caracalla und die Gesetze des Kaisers Iustinian. Aus den medizinischen Quellen stellt er hauptsachlich die Lehre von Hippokraates, Soranus und Galenos dar, die viele Informationen tber dem embryonalen Leben des Menschen uberliefert und die Møglichkeit der therapeutischen Abtreibung zugelassen haben. Aus den biblischen Quellen wird vor allem die Sentenz von Ex 21,22-23, ihre Ubertragung in der Septuaginta und ihr Widerhall bei Philon von Alexandrien und Joseph Flavius besprocien. Aus der Gesamtanalyse dieser Quellen geht hervor, daB in der vorchristlichen Zeit die Leibesfrucht vor der Geburt nicht als Mensch anerkanıt vordes war. Sie war mehr als pars viscerum matris, animal oder als Sache, dessen Vernichtung materiell ausgeglichen sein kann, betrachtet. 